\title{
National Assessment of Nor'easter-Induced Coastal Erosion Hazards: Mid- and Northeast Atlantic Coast
}

By Justin J. Birchler, P. Soupy Dalyander, Hilary F. Stockdon, and Kara S. Doran

Open-File Report 2015-1154

U.S. Department of the Interior

U.S. Geological Survey 


\section{U.S. Department of the Interior SALLY JEWELL, Secretary}

\section{U.S. Geological Survey \\ Suzette M. Kimball, Acting Director}

U.S. Geological Survey, Reston, Virginia: 2015

For more information on the USGS-the Federal source for science about the Earth, its natural and living resources, natural hazards, and the environment-visit http://www.usgs.gov or call 1-888-ASK-USGS (1-888-275-8747).

For an overview of USGS information products, including maps, imagery, and publications, visit http://www.usgs.gov/pubprod.

Any use of trade, product, or firm names is for descriptive purposes only and does not imply endorsement by the U.S. Government.

Although this information product, for the most part, is in the public domain, it also may contain copyrighted materials as noted in the text. Permission to reproduce copyrighted items must be secured form the copyright owner.

Suggested citation:

Birchler, J.J., Dalyander, P.S., Stockdon, H.F., and Doran, K.S., 2015, National assessment of nor'easter-induced coastal erosion hazards-Mid- and northeast Atlantic coast: U.S. Geological Survey Open-File Report 2015-1154 34 p., http://dx.doi.org/10.3133/ofr20151154.

ISSN 2331-1258 (online) 


\section{Acknowledgments}

The USGS National Assessment of Coastal Change Hazards Project Extreme Storms and Hurricanes group thanks the many scientists and research assistants who have contributed to the research and data collection that made this assessment possible. The authors thank the Joint Airborne Lidar Bathymetry Technical Center of Expertise (JALBTCX), as well as USGS field support and survey teams, for the comprehensive lidar dataset that formed the basis of this analysis. Daniel Sampson (Massachusetts Office of Coastal Zone Management) and Neil Ganju (USGS) provided thorough and thoughtful reviews.

Online mapping support was provided by Kathryn Smith and Heather Schreppel. This research has been supported by the USGS Coastal and Marine Geology Program. 


\section{Contents}

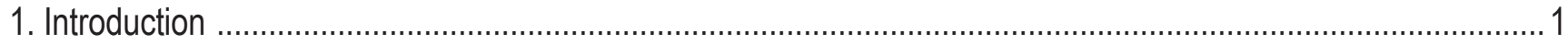

1.1 Impacts of Extreme Storms on Coastal Communities ……..................................................................... 1

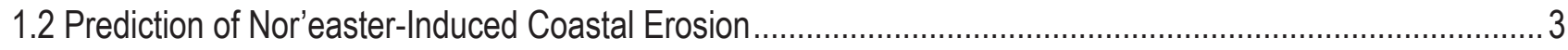

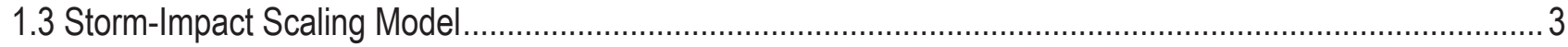

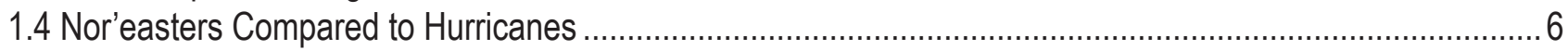

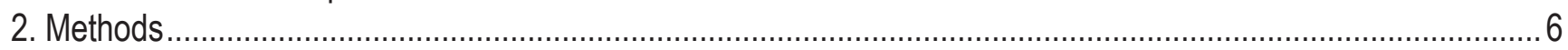

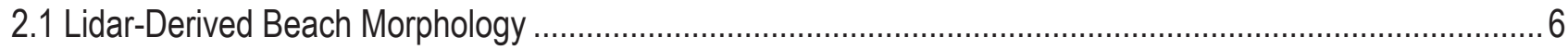

2.2 Nor'easter-Induced Water Levels ................................................................................................

2.2.1 Nor'easter Classification ...........................................................................................................

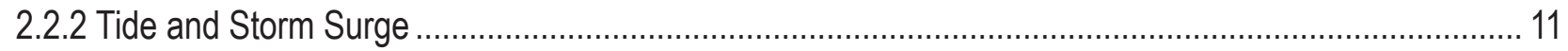

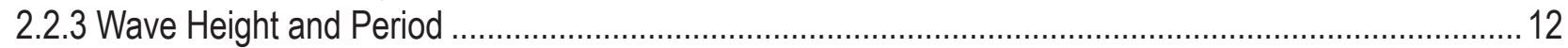

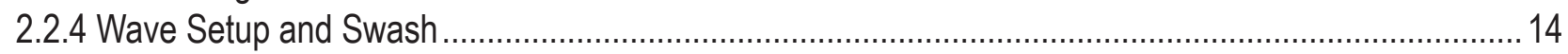

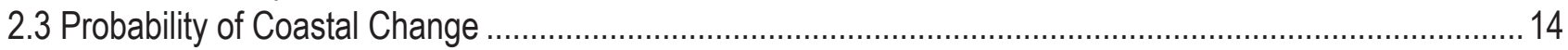

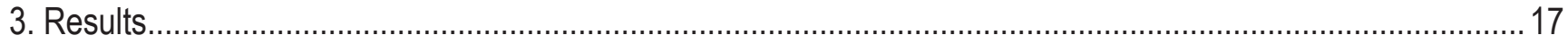

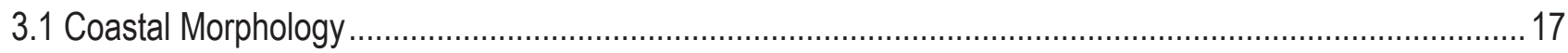

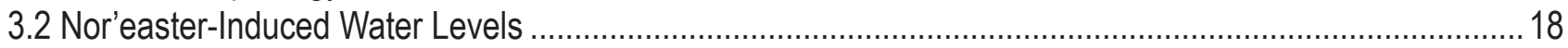

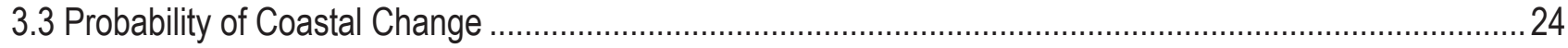

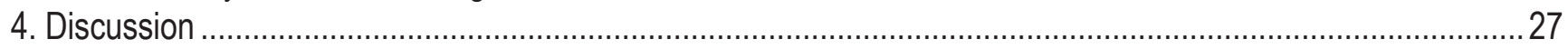

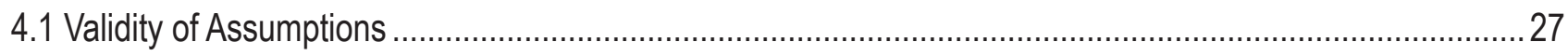

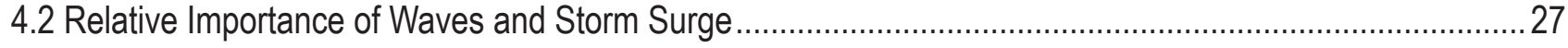

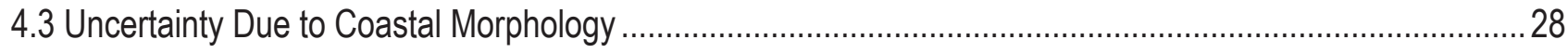

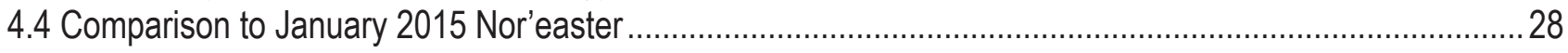

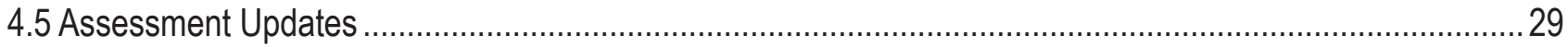

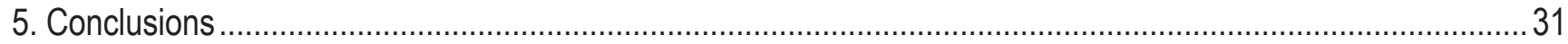

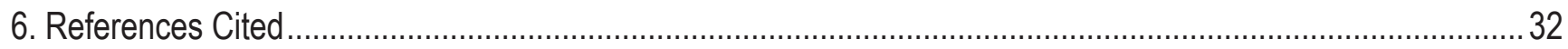

\section{Figures}

1. Waves and surge undercut a road in Massachusetts during a nor'easter in May 2005 ..............................

2. Waves and surge during the February 2013 nor'easter inundated the beach and dunes, flooding coastal roads in Scituate, Massachusetts.

3. Waves and surge overtop a seawall to damage infrastructure in Massachusetts, during a nor'easter in

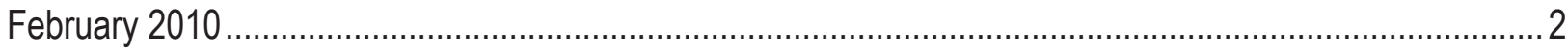

4. Sketch defining the relevant morphologic and hydrodynamic parameters in the storm-impact scaling

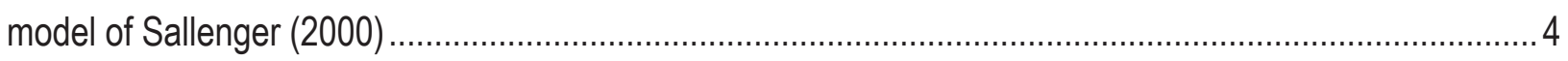

5. Examples of post-storm conditions after collision, overwash, and inundation .........................................

6. Map of coastal lidar surveys contracted by USGS in 2010 and 2012 for North Carolina, Virginia, Maryland, Delaware, New Jersey, New York, Rhode Island, Massachusetts, New Hampshire, and Maine.

7. Cross-shore profile of lidar gridded elevations indicating the locations of the dune crest, toe, shoreline, mean beach slope, mean high water, and high water line 
8. Cross-shore profile for a bluffed beach on Cape Cod, Massachusetts .................................................. 8

9. An example of the CFSR model hourly wind field in the study domain from northern Florida to

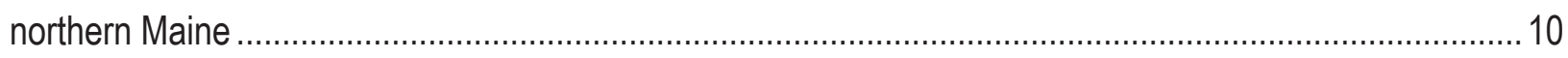

10. Nor'easter analysis study area along the Atlantic coast from North Carolina to Maine..............................15

11. CFSR model total storm surge elevation, maximum significant wave height, and dominant period, at the 20 meter isobath extending from North Carolina to Maine for class 1-3 nor'easters

12. Maximum shoreline water level for a category 1 hurricane and raw and smoothed dune crest elevation for a 1-kilometer alongshore section, and cumulative probability distribution of points in the top panel where the sum of $p$ over the range defines the probability of overwash

13. Distributions of dune crest elevation, dune toe elevation, and mean beach slope, for the mid- and northeast Atlantic sandy coastlines.

14. Distribution of dune crest and dune toe elevations for North Carolina, Virginia, Maryland, Delaware, New Jersey, New York, Rhode Island, Massachusetts, New Hampshire, and Maine. 20

15. Mean dune crest elevation for 1-kilometer sections of mid- and northeast Atlantic coastline compared to the standard deviation in those sections

16. Dune crest and dune toe elevations, nor'easter-induced mean, and maximum shoreline water levels extending from North Carolina to Maine.

17. Distributions of mean beach slope for North Carolina, Virginia, Maryland, Delaware, New Jersey, New York, Rhode Island, Massachusetts, New Hampshire, and Maine.

18. Probabilities of collision, overwash, and inundation during a class 1 nor'easter for the mid-Atlantic States and the Northeast States.

19. Probability of nor'easter-induced coastal change for the January 2015 nor'easter storm, and the class 1 nor'easter from this study, for the northeast Atlantic region

\section{Tables}

1. Difference between CFSR model simulated and observed non-tidal surge, significant wave height, and dominant wave period

2. Mean elevation of dune crest, dune toe, and mean beach slope for the sandy beaches along the northeast Atlantic coast.

3. Mean input wind speed, significant wave height, wave period, modeled setup, runup, and storm surge for class 1-3 nor'easters.

4. Percentage of coast very likely to experience erosion associated with collision, overwash, and inundation during class 1-3 nor'easters. 


\section{Conversion Factors}

International System of Units to Inch/Pound

\begin{tabular}{ccc}
\hline Multiply & By & To obtain \\
\hline & Length & \\
\hline centimeter $(\mathrm{cm})$ & 0.3937 & inch (in.) \\
millimeter $(\mathrm{mm})$ & 0.03937 & inch (in.) \\
meter $(\mathrm{m})$ & 3.281 & foot $(\mathrm{ft})$ \\
kilometer $(\mathrm{km})$ & 0.6214 & mile $(\mathrm{mi})$ \\
kilometer $(\mathrm{km})$ & 0.5400 & mile, nautical $(\mathrm{nmi})$ \\
meter $(\mathrm{m})$ & 1.094 & yard $(\mathrm{yd})$ \\
kilometer $(\mathrm{km})$ & 0.621 & mile $(\mathrm{mi})$ \\
\hline & Flow rate \\
\hline meter per second $(\mathrm{m} / \mathrm{s})$ & 2.237 & mile per hour $(\mathrm{mi} / \mathrm{h})$ \\
\hline
\end{tabular}

\section{Datum}

Vertical coordinate information is referenced to the North American Vertical Datum of 1988 (NAVD88).

Horizontal coordinate information is referenced to the North American Datum of 1983 (NAD83).

\section{Abbreviations}

$\begin{array}{ll}\text { ADCIRC } & \text { Advanced Circulation model } \\ \text { CFSR } & \text { Climate Forecast System Reanalysis } \\ \text { CHARTS } & \text { Compact Hydrographic Airborne Rapid Total Survey } \\ \text { EAARL } & \text { Experimental Advanced Airborne Research Lidar } \\ \text { ESTOFS } & \text { Extratropical Surge and Tide Operational Forecast System } \\ \text { GPS } & \text { global positioning system } \\ \text { HWL } & \text { high water line } \\ \text { IPCC } & \text { Intergovernmental Panel on Climate Change } \\ \text { lidar } & \text { light detection and ranging } \\ \text { MHW } & \text { mean high water } \\ \text { NCEP } & \text { National Centers for Environmental Prediction } \\ \text { NOAA } & \text { National Oceanic and Atmospheric Administration } \\ \text { NWW3 } & \text { NOAA WaveWatchlll model } \\ \text { PHOTOSCI } & \text { Photo Sciences Inc. lidar contractor (now Quantum Spatial) } \\ \text { RMS } & \text { root mean square } \\ \text { USACE } & \text { U.S. Army Corps of Engineers } \\ \text { USGS } & \text { U.S. Geological Survey } \\ \text { WOOLPERT } & \text { Woolpert, Inc. lidar contractor }\end{array}$




\title{
National Assessment of Nor'easter-Induced Coastal Erosion Hazards: Mid- and Northeast Atlantic Coast
}

\author{
By Justin J. Birchler, P. Soupy Dalyander, Hilary F. Stockdon, and Kara S. Doran
}

\section{Introduction}

\subsection{Impacts of Extreme Storms on Coastal Communities}

Beaches serve as a natural buffer between the ocean and inland communities, ecosystems, and natural resources. However, these dynamic environments move and change in response to winds, waves, and currents. During extreme storms, changes to beaches can be great, and the results are sometimes catastrophic. Lives may be lost, communities destroyed, and millions of dollars spent on rebuilding.

During storms, large waves may erode beaches, and high storm surge may shift the erosive force of the waves higher on the beach. In some cases, the combined effects of waves and surge may cause overwash (when waves and surge overtop the dune, transporting sediment inland) or flooding. Buildings and infrastructure on or near a dune can be undermined during wave attack and subsequent erosion. A number of strong northeast storms - storms with winds tending to blow from the northeast direction (see Section 1.4) - referred to as nor'easters, have hit the mid- and northeast Atlantic coast of the United States in recent years (February 2013 and January 2015). Waves from these storms caused severe erosion, flooding, and undermining of roads in many areas along the northeast Atlantic coast (figs. 1-3).

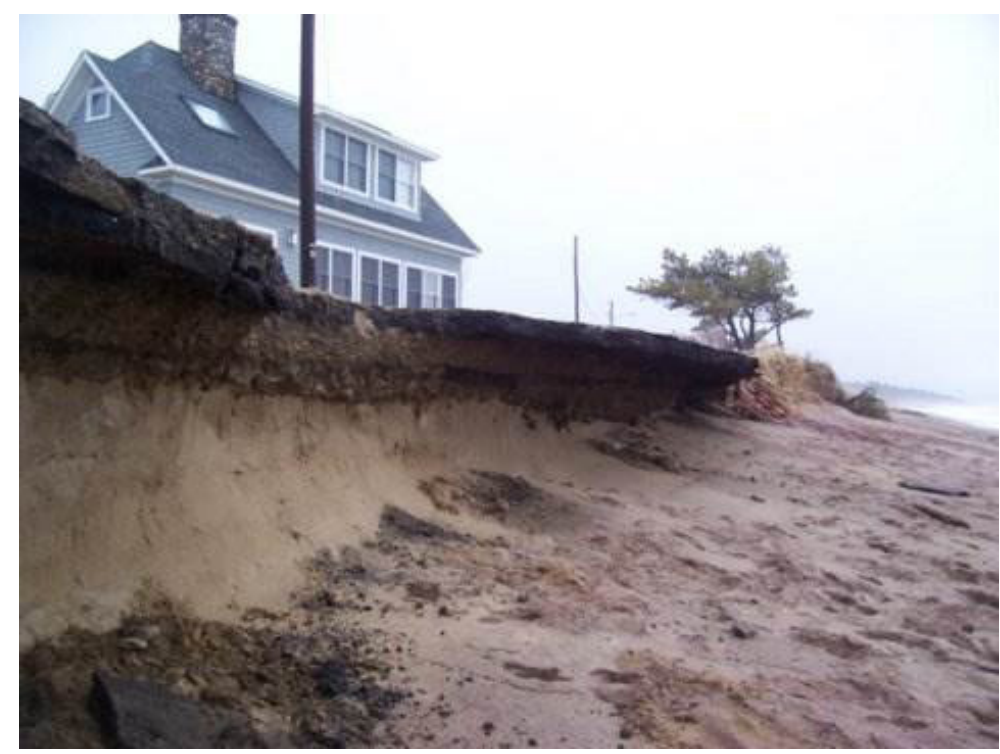

Figure 1. Waves and surge undercut a road in Massachusetts during a nor'easter in May 2005. (Photo credit: John Cannon, NOAA) 


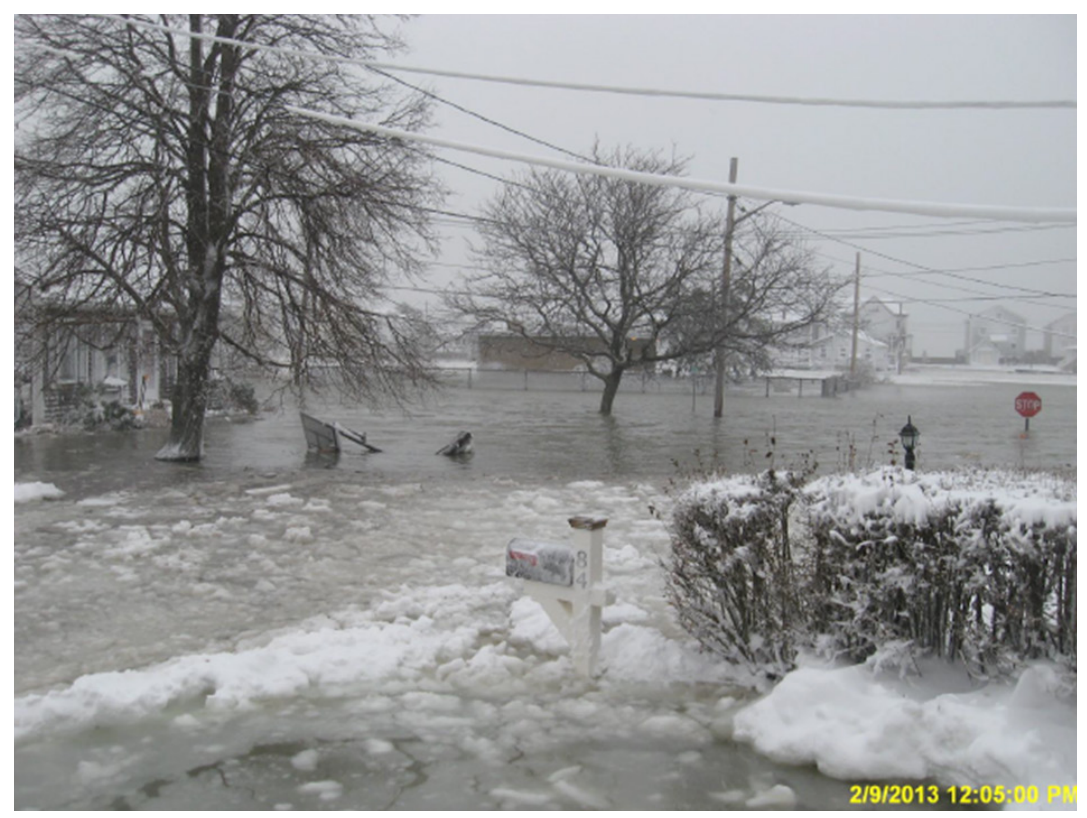

Figure 2. Waves and surge during the February 2013 nor'easter inundated the beach and dunes, flooding coastal roads in Scituate, Massachusetts. (Photo credit: Jason Burtner, Massachusetts Office of Coastal Zone Management)

Waves overtopping a dune can transport water and sand inland, covering roads and blocking evacuation routes or impeding emergency relief (fig. 2). If storm surge inundates barrier island dunes, currents flowing across the island can create a breach, or a new inlet, completely severing evacuation routes.

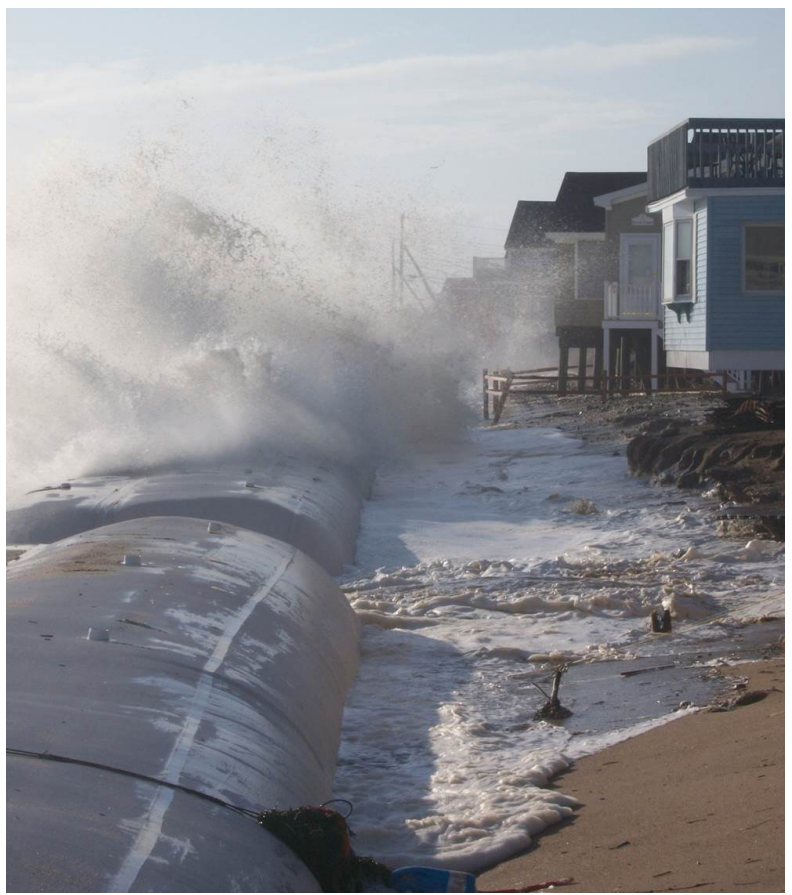

Figure 3. Waves and surge overtop a seawall to damage infrastructure in Massachusetts, during a nor'easter in February 2010. (Photo credit: John Cannon, NOAA) 
Extreme coastal changes caused by hurricanes or nor'easters may increase the vulnerability of communities both during a storm and to future storms (fig. 3). For example, when sand dunes are substantially eroded, inland structures are exposed to storm surge and waves. On barrier islands, absent or low dunes allow water to flow inland across the island.

\subsection{Prediction of Nor'easter-Induced Coastal Erosion}

Waves and surge accompanying hurricanes, tropical storms, and nor'easters may result in widespread beach and dune erosion and extensive overwash. A clear need exists to identify areas of coastline that are likely to experience severe erosion during extreme storms. This information can be used to determine vulnerability levels and the associated risk of building houses or infrastructure on land that shifts and moves with each storm landfall. The coastal morphology of the mid- and northeast Atlantic region includes both sandy beaches and rocky coasts. Because rocky coasts tend to be more resilient to storms, and our formulations are specifically designed for open-coast sandy beaches, the focus in this report is open-coast sandy beaches on the U.S. mid- and northeast Atlantic shoreline. Non-open coasts (for example, within southern Cape Cod Bay and on the back side of Cape Cod) along with rocky coasts are not included in this analysis.

Communities along the mid- and northeast Atlantic coast of the United States are often affected by nor'easters. Dolan and Davis (1992a) identified 1,347 northeast storms from 1942 to 1984 at Cape Hatteras, North Carolina; about 30 nor'easters affected the Atlantic coast each year during the 42-year study period. The majority of storms and the strongest storms occur from October to April, though nor'easters were observed in every month of the year (Davis and others, 1993). Nor'easters, though usually weaker than hurricanes, are perhaps more important drivers of coastal erosion in this region because they are more frequent and, because of their slow movement, can affect the coast for days rather than hours (Zhang and others, 2001).

A decade of research within the U.S. Geological Survey (USGS) National Assessment of Coastal Change Hazards project on storm-driven coastal change hazards has provided the data and modeling capabilities to produce the first regional assessment of the vulnerability of coastlines to extreme erosion during nor'easters. Vulnerability is defined in terms of the probability for coastal change, predicted using a USGS-developed storm-impact scale that compares predicted elevations of nor'easter-induced water levels to measured elevations of coastal topography (Sallenger, 2000).

\subsection{Storm-Impact Scaling Model}

The combined effects of the astronomical high tide and storm effects of storm surge and wave runup (both setup, $\eta_{\text {setup }}$, and swash, $S$ ) move the erosive forces of waves higher on the beach than during typical lower energy conditions. The total elevation of these three parameters defines two key metrics that characterize the nearshore hydrodynamic forcing of a storm: (1) the extreme high water level attained during a storm, defined here as the 98-percent exceedance level $\left(\eta_{98}\right)$, and $(2)$ the storm-induced mean water level $\left(\eta_{50}\right)$, defined by only storm surge, tide, and wave setup.

Water-level elevations are compared to the elevation of the toe $\left(z_{t}\right)$ and crest $\left(z_{c}\right)$ of the most seaward sand dune that defines the landward limits of the beach system and represents the first-line defense of a barrier island to an approaching storm. Using these parameters, four storm-impact regimes, or thresholds for coastal change, have been defined to provide a framework for examining the general 
types and relative magnitudes of coastal change that are likely to occur during storms, such as nor'easters (fig. 4) (Sallenger, 2000; Stockdon and others, 2007a). These storm-impact regimes are:

- $\operatorname{swash}\left(\eta_{98}<z_{t}\right)$

- $\operatorname{collision}\left(\eta_{98}>z_{t}\right)$

- overwash $\left(\eta_{98}>z_{c}\right)$

- inundation $\left(\eta_{50}>z_{c}\right)$

(Note: Following Plant and Stockdon (2012), our nomenclature differs from Sallenger (2000) to emphasize probabilistic definition of water levels and to clearly distinguish both the horizontal and vertical components of dune morphology.)

The swash regime represents a range of relatively calm weather conditions, where water levels are confined to areas seaward of the dune base. Sand that is eroded from the beach during more energetic periods is generally transported offshore and may be returned to the beach during more quiescent conditions. The erosion and recovery cycle can occur over a time span on the order of weeks. When waves reach the base of the dune (collision regime), the front of the dune is expected to erode (fig. 5, left). Again, sand is transported seaward and then re-deposited on the beach or sandbar. In this case, the beach is likely to recover in the weeks and months following the storm. However, because aeolian processes are responsible for natural dune growth, recovery of the dune may take years. Some portion of the total sand transport is directed alongshore, but the gradients of alongshore transport are assumed to be small for the purposes of these assessments.

In extreme cases, such as during stronger storms and for relatively lower dunes, waves and surge may exceed the dune crest elevation (overwash regime). Under these conditions, waves transport sand landward from the beach and dune (fig. 5, center). Impacts may be more long-lasting in this regime as sand is deposited inland, making it unavailable for natural recovery of the beach and dune following a storm. During the inundation regime (fig. 5, right), storm-induced mean water levels exceed the elevation of the crest of the primary dune or berm. Some of the most extreme coastal changes on barrier

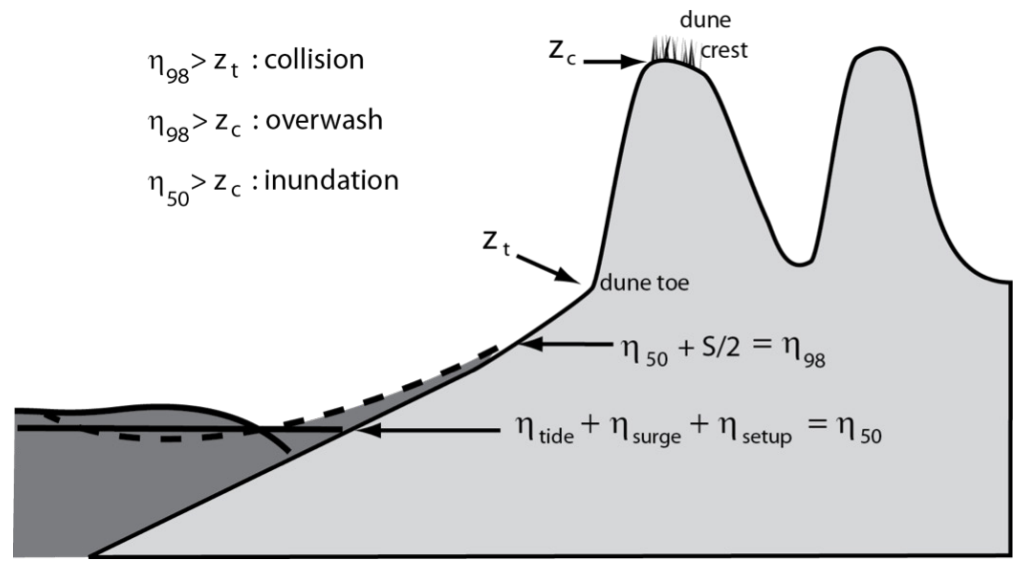

Figure 4. Sketch defining the relevant morphologic and hydrodynamic parameters in the storm-impact scaling model of Sallenger (2000) (modified from Stockdon and others, 2009). All parameters measured as elevation with units of meters. See text for parameter explanation. 
Collision

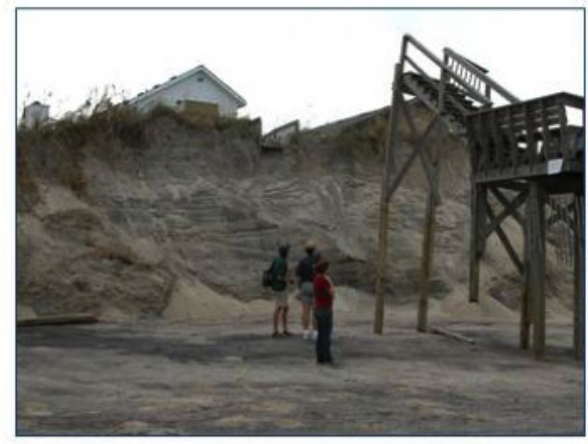

Overwash

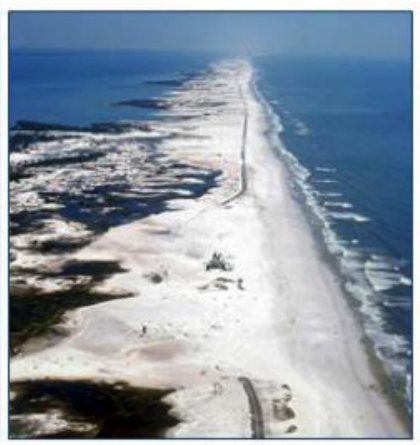

Inundation

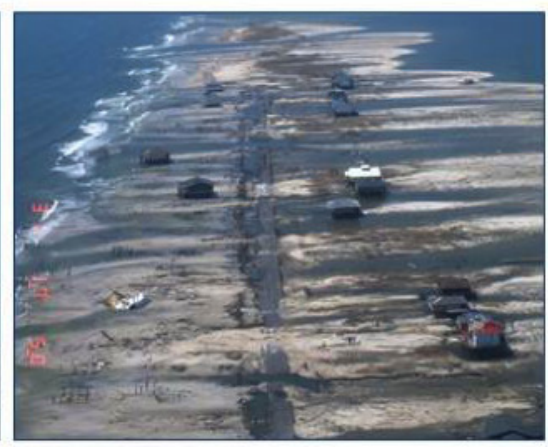

Figure 5. Examples of post-storm conditions after collision (Nags Head, North Carolina; Hurricane Isabel, 2003), overwash (Santa Rosa Island, Florida; Hurricane Ivan, 2004), and inundation (Dauphin Island, Alabama; Hurricane Katrina, 2005).

islands occur within this regime; the beach system (dune crest and beach) is completely submerged, and net landward transport of sediment is likely to occur (Sallenger, 2000). Typically, larger magnitudes of shoreline retreat and beach erosion will occur when the dune is inundated as a result of sand transport occurring under all storm-scale regimes (Stockdon and others, 2007a). On narrow barrier islands, inundation allows strong currents to cross the island and focus erosion where dunes are low, thus carving breaches.

The predictive accuracy of the storm-impact scaling model was tested by hindcasting the likely impacts of Hurricanes Bonnie (1998) and Floyd (1999) (Stockdon and others, 2007a) and of Hurricane Ivan (2004) (Stockdon and others, 2007b) and comparing these with observed morphologic changes. For Hurricane Bonnie, the overall hindcast accuracy of the model in predicting one of the four regime types was 51 percent, while the accuracy for Floyd was a slightly improved 58 percent. For Hurricane Ivan, the overall hindcast accuracy of the model in predicting one of the four regime types was 68 percent. The accuracy of the model varied among regimes and was highest for the overwash conditions. When using forcing from the actual storm to test the model, underprediction of the actual storm response was more likely than overprediction. Prediction errors were likely due to profile evolution of the barriers during the storm. Waves and surge may erode the beach and dune for several tidal cycles before the storm makes landfall. If substantial dune erosion occurs, the beach will be more vulnerable to overwash and inundation than the initial, pre-storm morphology indicated.

Skillful hindcast results (Stockdon and others, 2007a, 2007b) indicated the model was robust enough to be applied in real time for landfalling hurricanes (Plant and others, 2010; see also http://coastal.er.usgs.gov/hurricanes/sandy/coastal-change/). Using pre-storm measurements of dune elevations and real-time forecasts of storm surge and wave conditions in conjunction with the storm-impact scaling model, the USGS routinely reports the likelihood of beaches experiencing coastal change associated with collision, overwash, and inundation during landfalling hurricanes. These analyses are posted online (http://coastal.er.usgs.gov/hurricanes/) and revised with updated hydrodynamic forecasts as a storm approaches landfall.

Using a methodology similar to the real-time hurricane forecasts, this report quantifies the likely impact of hypothetical nor'easters on the U.S. mid- and northeast Atlantic coastline, including North Carolina, Virginia, Maryland, Delaware, New Jersey, New York, Rhode Island, Massachusetts, New Hampshire, and Maine. The probabilities of nor'easter-induced coastal change are used to define the 
vulnerability of this region to extreme erosion from waves and storm surge associated with class 1-3 nor'easters, which are defined below. This report, along with analyses of hurricane-induced coastal change for the Gulf of Mexico shorelines (Stockdon and others, 2012), southeast Atlantic shorelines (Stockdon and others, 2013), mid-Atlantic shorelines (Doran and others, 2013), and northeast Atlantic shorelines (Birchler and others, 2014), forms the basis of a national assessment of storm-induced coastal erosion hazards.

\subsection{Nor'easters Compared to Hurricanes}

Both hurricanes and nor'easters occur in the North Atlantic, are characterized by strong winds and large waves, are typically accompanied by heavy precipitation, and can cause substantial coastal erosion. Hurricanes are warm-core cyclones that form in the tropical waters of the Atlantic and move northwest of their formation location. Hurricanes are strong, well-organized low pressure systems and typically influence a fairly small area, about 150 kilometers $(\mathrm{km})$ in diameter (Zhang and others, 2001). Nor'easters are cold-core extratropical cyclones that often form along the U.S. mid-Atlantic coast and move northeastward as they strengthen (Dolan and Davis, 1992a; Butman and others, 2008). Nor'easters are diffuse and weaker low pressure systems in which wind speeds typically are less than those of a category 1 hurricane (about 33 meters per second $[\mathrm{m} / \mathrm{s}]$ ). Nor' easters occur more frequently than hurricanes, are much larger in size, and can continue for several days and affect almost the entire U.S. East Coast (Zhang and others, 2001).

\section{Methods}

In order to use the storm-impact scaling model for a large-scale assessment of the potential for coastal change during future nor'easters, accurate estimates of the dune parameters and the expected storm-induced water level, including storm surge and wave contributions, for hypothetical storms are needed. Light detection and ranging (lidar) topographic surveys were used to accurately measure dune elevations along extended (hundreds of kilometers) lengths of coastline. The Climate Forecast System Reanalysis (CFSR) model (Saha and others, 2010) was used to estimate local winds and still water levels. Archived National Oceanic and Atmospheric Administration (NOAA) WaveWatchIII (NWW3) model results using winds from the CFSR model were used for wave conditions (Chawla and others, 2013). The combination of high-resolution measurements and advanced hydrodynamic modeling makes it possible to estimate probabilities of storm-induced coastal change and to identify coastal erosion vulnerability at a national scale.

\subsection{Lidar-Derived Beach Morphology}

The topography of the beaches and dunes was mapped using airborne lidar topographic surveys contracted by the USGS in 2010 and 2012. Survey data from 2012 were used where it was available (predominantly in regions impacted by Hurricane Sandy in October 2012) and supplemented with the 2010 data (fig. 6). The combination of laser-based ranging with inertial and global positioning system (GPS)-based navigation provides an efficient method for collecting high-resolution data of sub-aerial topography with sufficient accuracy (root-mean-square [RMS] vertical accuracy $=15$ centimeters $[\mathrm{cm}]$; horizontal accuracy $=1-1.5$ meters $[\mathrm{m}])$ to resolve the spatial details of sand-dune elevation and position (Sallenger and others, 2003). Three-dimensional lidar data were gridded using a fixedscale interpolator (Plant and others, 2002), which allows for variability in cross-shore and alongshore 
resolution, in this case, $2.5 \mathrm{~m}$ and $10 \mathrm{~m}$, respectively. In addition to a gridded topographic surface, this method produces a corresponding grid of the RMS error, which provides a measure of noise in the data. A Hanning filter with a width equal to two times the grid resolution was chosen to minimize noise in the data associated with vegetation, alongshore variability, and other error sources while preserving distinct morphology. Analysis of cross-shore profiles of gridded data allows for automated extraction of dune crest $\left(x_{c}, z_{c}\right)$ and toe $\left(x_{t}, z_{t}\right)$, as well as shoreline position $\left(x_{s l}, z_{s l}\right)$, and beach slope $\left(\beta_{m}\right)$, at a regular alongshore interval of, in this case, $10 \mathrm{~m}$ (fig. 7). Here, $\mathrm{x}$ represents the cross-shore position and $\mathrm{z}$ represents the vertical elevation of the dune features. These features are ultimately used to estimate wave runup and the corresponding storm-response regimes, as well as to quantify actual morphologic changes before and after storms. Detailed descriptions of the algorithm used to extract shoreline position, dune crest and toe, and beach slope can be found in the first report of this series, "National Assessment of Hurricane-Induced Coastal Erosion Hazards: Gulf of Mexico" (Stockdon and others, 2012), and references contained therein.

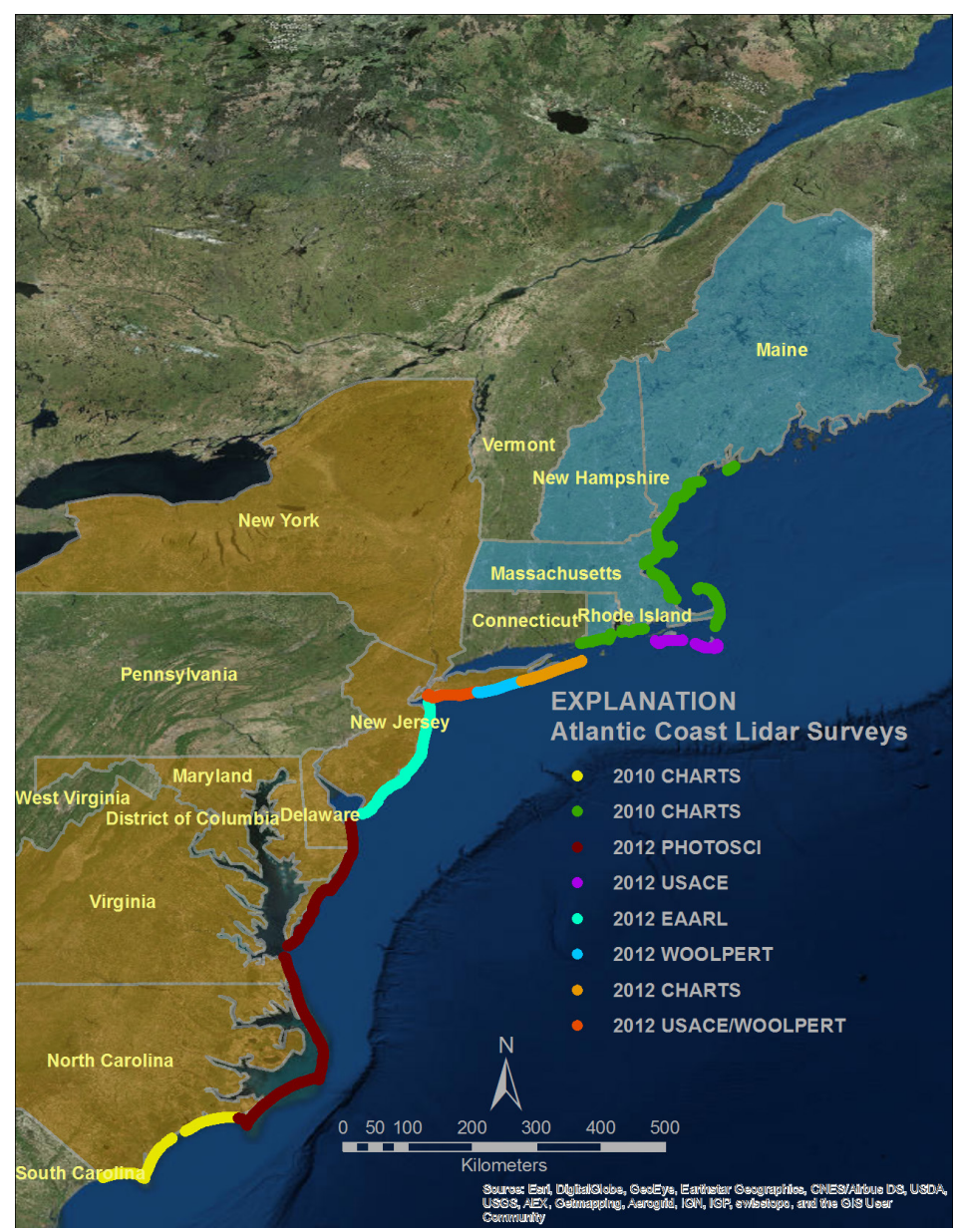

Figure 6. Map of coastal lidar surveys contracted by USGS in 2010 and 2012 for North Carolina, Virginia, Maryland, Delaware, New Jersey, New York, Rhode Island, Massachusetts, New Hampshire, and Maine. The surveys from 2012 were conducted in November following Hurricane Sandy. The "midAtlantic coast" States are highlighted in orange and the "northeast Atlantic coast" States are highlighted in blue. Lidar survey names are explained in the Abbreviations table at the front of the report. 
Where dune-backed beaches were not present, alternate methods were used to identify $z_{c}$. Aerial imagery was used to identify areas with rocky coastlines. In these regions, dune parameters mistakenly selected by the automated method were rejected and are not included in subsequent analyses. Bluffed coasts, composed of consolidated sands, were easily identified using the cross-shore elevation profiles because the bluff crest height is much greater than that of a typical sand dune (fig. 8). Bluff crests sometimes exceeded $40 \mathrm{~m}$ in elevation. Where there was a dune seaward of the bluff, typical dune parameters were selected; otherwise, the bluff crest was chosen as the dune crest.

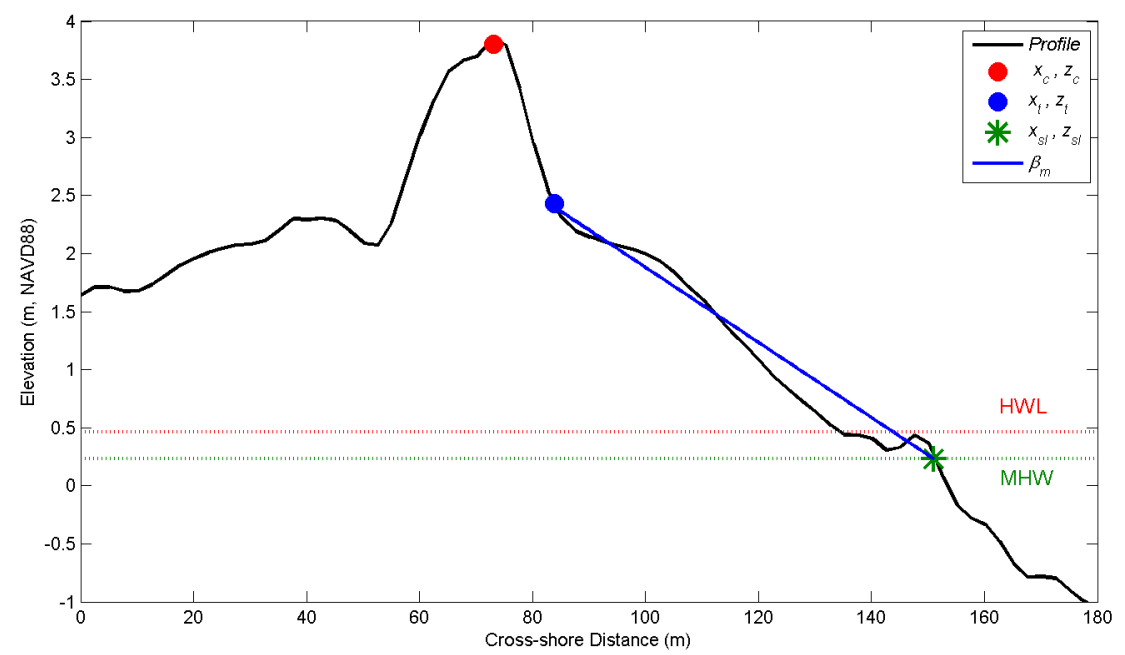

Figure 7. Cross-shore profile of lidar gridded elevations indicating the locations of the dune crest $\left(x_{c}, z_{c}\right)$, toe $\left(x_{t}, z_{t}\right)$, shoreline $\left(x_{s \mid}, z_{s l}\right)$, mean beach slope $\left(\beta_{m}\right)$, mean high water (MHW), and high water line (HWL). Abbreviations: $m$, meter; NAVD88, North American Vertical Datum of 1988.

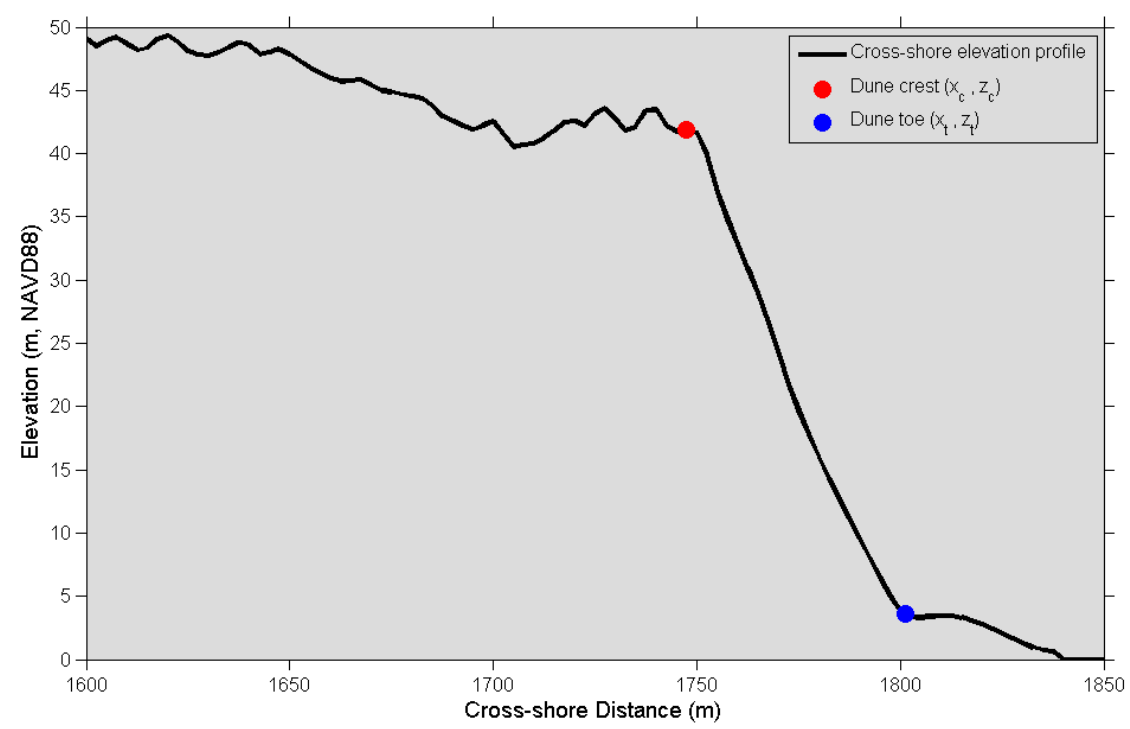

Figure 8. Cross-shore profile for a bluffed beach on Cape Cod, Massachusetts. The black line represents the lidar-derived elevation. Abbreviations: m, meter; NAVD88, North American Vertical Datum of 1988. 


\subsection{Nor'easter-Induced Water Levels}

During a nor'easter, water levels at the shoreline include the combined effects of tide, storm surge, and local wave energy. Predictions of coastal change during nor'easters require estimates of both the mean and extreme water levels. The mean nor'easter-induced water level, $\eta_{50}$, is defined as

$$
\eta_{50}=\eta_{\text {surge }}{ }^{\prime}+\eta_{\text {setup }}
$$

where $\eta_{\text {surge }}$ ' is the total storm surge elevation (see equation 3 ), and $\eta_{\text {setup }}$ is wave setup, the superelevation of the water surface at the shoreline due to wave breaking. The extreme water level $\left(\eta_{98}\right)$ attained during the storm includes wave swash, the time-varying component of wave energy on the beach, and is defined as

$$
\eta_{98}=\eta_{50}+1.1(S / 2)
$$

where $S$ is the total swash excursion about the setup level and the 1.1 multiplier corrects for parameterization bias (see Stockdon and others, 2006). It is important to note that both the mean and maximum water levels include a contribution from waves. Stockdon and others (2007a) found that for low category hurricanes, waves increased water levels at the shoreline by the same magnitude as storm surge; given that the wind speeds associated with nor'easters are typically weaker than for hurricanes, waves are expected to make a similar contribution for these types of storms. The following sub-sections explain how the worst-case scenario for each class of nor'easter was determined; the worst-case scenario was defined as maximum tide elevation, maximum surge elevation, and highest wave height and period coinciding to lead to the greatest nor'easter-induced water levels.

\subsubsection{Nor'easter Classification}

Although hurricanes are typically classified using the well-known Saffir-Simpson Hurricane Wind Scale (Simpson, 1974), there is no similar scale for nor'easter winds. Existing nor'easter scales characterize storms on the basis of their track and origin (Dolan and Davis, 1992; Davis and others, 1993); climatological parameters such as minimum pressure and deepening rate (Hart and Grumm, 2001; Zielinski, 2002); or power indices that include magnitude and duration (Zhang and others, 2001). Because the coastal erosion potential of nor'easters is tied to wave height and hence wind speed (and fetch for more sheltered embayments), these classifications are not well suited for the purpose of characterizing nor'easters. Dolan and Davis (1992) and Davis and others (1993) used wave height to characterize storms, but did not explicitly tie that parameter to wind speed, and Hirsch and others (2001) used closed cell circulation parameters and arbitrary wind speeds ("storm" defined as winds greater than $10.3 \mathrm{~m} / \mathrm{s}$, "strong storm" defined as winds greater than $23.3 \mathrm{~m} / \mathrm{s}$ ) to define the existence of east coast winter storms. In the current analysis, maximum wind speed was chosen as a metric that can be measured for an incoming storm before it reaches a particular site, and that is expected to delineate the storm's potential for coastal change.

The CFSR model from the National Centers for Environmental Prediction (NCEP) is a global, high resolution, coupled atmosphere-ocean-land surface-sea ice system. It was initially run for a 31-year period from 1979 to 2009 and includes hourly forecasts (Saha and others, 2010). The CFSR winds had a 


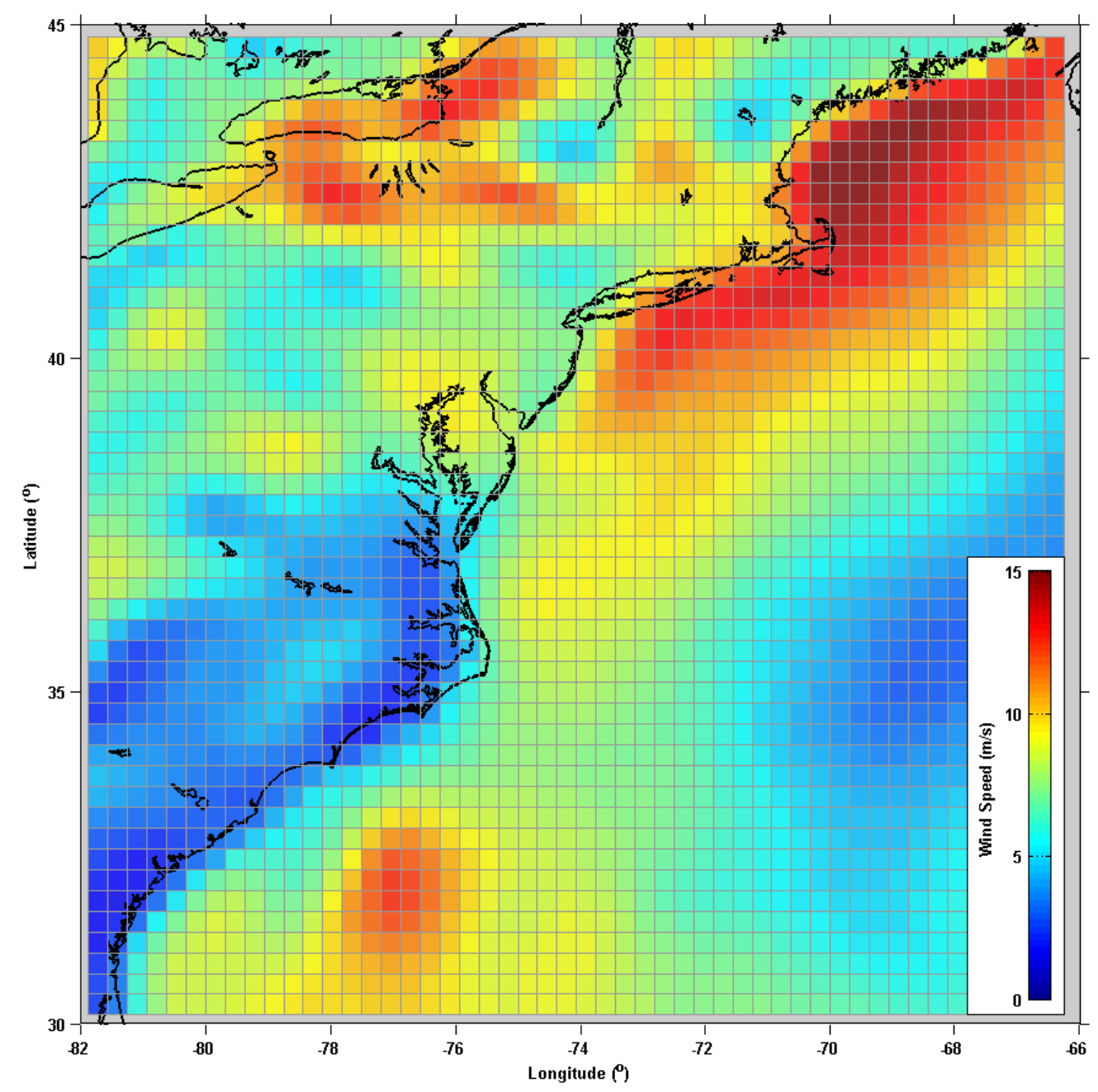

Figure 9. An example of the CFSR model hourly wind field in the study domain from northern Florida to northern Maine. Gridlines show 0.3 degree resolution of wind speeds ranging from 0 to $15 \mathrm{~m} / \mathrm{s}$, and the coastline is shown in black. Abbreviation: $\mathrm{m} / \mathrm{s}$, meters per second.

resolution of 0.3 degrees (fig. 9), the CFSR water levels had a resolution of 0.5 degrees, and the NWW3 wave conditions from CFSR winds had a resolution of 0.067 degrees (4 arc-minute resolution) (Chawla and others, 2013).

Nor'easter intensity was classified using three ranges of wind speeds:

Class 1: wind speed $6-12 \mathrm{~m} / \mathrm{s}$,

Class 2: wind speed $12-18 \mathrm{~m} / \mathrm{s}$, and

Class 3: wind speed $>18 \mathrm{~m} / \mathrm{s}$.

These classes were chosen by looking at the resulting water levels for these ranges of wind speeds and delineating classes where storm impacts could be distinguished. Unlike hurricanes, which typically consist of a low pressure center surrounded by a relatively organized wind and pressure field, extratropical (cold core) storms such as nor'easters may have multiple secondary low pressure centers associated with the same storm system (Zielinski, 2002). For the purpose of characterizing nor'easters, the specifics of the underlying wind and pressure cell organization are ignored, and the maximum wind 
speed associated with a system is used as the metric. For each hour of CFSR output over the model duration of 1979-2009 during the winter and spring months of December-May, the maximum sustained wind speed at $10 \mathrm{~m}$ height was identified within the study domain (fig. 9). This wind speed was then used to identify if simulated conditions for that hour were associated with a class 1, 2, or 3 nor'easter (or if wind speeds were less than $6 \mathrm{~m} / \mathrm{s}$, that is, no storm present). Data for the North Atlantic hurricane season (June 1-November 30) were excluded from the analysis so as to not confound the nor'easter data with hurricane conditions. The model output hours associated with each nor'easter class were used to find the spatially variant worst-case scenario storm surge water level, significant wave height, and dominant wave period for that class.

\subsubsection{Tide and Storm Surge}

Tidal water levels are not included in the CFSR model simulations; therefore, this component was added to model predictions of storm surge. Because the goal of this report is to quantify the worst probable damage for each of the classes, high tide levels were used. In addition, a comparison between CFSR still water levels and observational tide gage data identified a systematic underprediction of storm surge in the model that needed to be corrected. The total elevation of storm surge was found by summing (1) the estimated high tide elevation $\left(\eta_{\text {tide }}\right),(2)$ the CFSR simulated non-tidal water level $\left(\eta_{\text {surge }}\right)$, and (3) an offset between the CFSR model and observed gage data at six locations along the coast $\left(\eta_{\text {offse }}\right)$, which is discussed below. The total storm surge $\left(\eta_{\text {surge }}^{\prime}\right)$ is given by the following equation:

$$
\eta_{\text {surge }}{ }^{\prime}=\eta_{\text {tide }}+\eta_{\text {surge }}+\eta_{\text {offset }}
$$

Water levels are not solely correlated to atmospheric conditions at any given time, but instead include time-lagged effects from non-local conditions due to, for example, wind wave propagation time. In addition, the worst-case scenario captured here is based on assuming the highest water levels from surge and waves correspond in time, which for historic storms may not have been the case. The predicted surge elevations $\left(\eta_{\text {surge }}\right)$ for class 1-3 nor'easters were extracted from CFSR data from 1979 to 2009 along the $20 \mathrm{~m}$ isobath. Therefore, the surge associated with each hour was defined as the maximum non-tidal elevation in the surrounding 24-hour period. For each nor'easter class and alongshore location, the CFSR-simulated surge elevation was calculated as the $99^{\text {th }}$ percentile of those hourly non-tidal water levels when the wind speed fell within that class.

The CFSR model references sea surface height to the model's estimate of still water surface, whereas water level gage data and lidar topography are referenced to the North American Vertical Datum of 1988 (NAVD88). In addition, the model only accounts for the relatively small contribution of density-driven steric sea level rise and does not account for sea level rise associated with ice melt or local and regional land subsidence. Furthermore, sea surface height data are not assimilated in the model, and thus the output may have associated regional errors (Xue and others, 2010). Therefore, water level observations were used to adjust the model to NAVD88 and present day sea level elevation, and to account for regional model error. Simulated water levels were compared to observed non-tidal surge levels at the six gage locations (table 1). For each of the six gages, local sea level rise was estimated as a linear trend fit to the time series of non-tidal water level (observed water level minus predicted tide). This trend was then used to adjust the water level time series to present day sea level rise. Doing so results in older storms having the same surge as they would have under present day sea level, as opposed 
to the actual conditions of the storm when sea level was lower. Using the water levels corrected for sea level rise, the $99^{\text {th }}$ percentile of surge for each nor'easter class and the difference between simulated and observed water levels was calculated for each gage, and this difference was averaged over all six sites. The simulated water levels were consistently lower than the observed water levels by $0.46 \mathrm{~m}, 0.68 \mathrm{~m}$, and $0.88 \mathrm{~m}$ for class 1-3 nor'easters, respectively (table 1 ). The standard deviation of the offset within each class was fairly low and was consistent in the alongshore; 0.07, 0.31, and 0.29 $\mathrm{m}$ for class 1-3, respectively. The mean offset for each nor'easter class was applied at every location alongshore.

In order to calculate the tidal contribution $\left(\eta_{\text {tide }}\right)$, the $95^{\text {th }}$ percentile of predicted tidal water level elevations (relative to NAVD88) was calculated from six long-running tide gages and interpolated to each analysis location in the alongshore (see table 1). These high tide elevations were identical for all nor'easter classes at each location. This approach allows tidal predictions to be based on harmonic analysis of long-running observations, at a cost of relying on limited spatial coverage in data; interpolating these data may result in errors where there is localized tidal variability. The estimated high tide elevation was compared to the tidal water level variability reconstructed for the 1-year period of 2010 from the ADvanced CIRCulation model (ADCIRC) Western North Atlantic, Caribbean, and Gulf of Mexico 2001 tidal database, which is estimated to have an error of 6-14 percent for each tidal constituent (Mukai and others, 2002). The $95^{\text {th }}$ percentile of tidal water elevations simulated by ADCIRC were on average $16 \mathrm{~cm}$ higher at the tide gage locations than values calculated from the gage predicted tides. For the mid-Atlantic region, the alongshore interpolated tidal level was $17 \mathrm{~cm}$ lower than the ADCIRC value. The alongshore interpolated tidal level in the northeast Atlantic was $23 \mathrm{~cm}$ higher than the ADCIRC value, with higher spatial variability in error than in the mid-Atlantic (standard deviation of error was 11 and $36 \mathrm{~cm}$ for the mid- and northeast Atlantic regions, respectively). Because the magnitude of error in the $95^{\text {th }}$ percentile of tidal water level elevation was similar to the spatial variability in difference computed between interpolated values from the gage data and model output, the interpolated values were used. Overall this estimated uncertainty is small compared to storm water levels.

\subsubsection{Wave Height and Period}

Wave conditions vary spatially and temporally during nor'easters. Because the wave runup calculations require wave information at a specific shallow water depth (20 m depth contour) (fig. 10), the height of storm waves tends to be limited by dissipation due to bottom friction.

Significant wave height $\left(H_{s}\right)$ and dominant wave period $\left(T_{p}\right)$ data were taken from an archived NWW3 model run using winds from the CFSR model (Chawla and others, 2013). In the case of waves, output is archived every 3 hours. For each hourly wind point, wave height and period values were defined as the maximum in the surrounding 24 hours. As with still water levels, for each storm class and at each alongshore location, the $99^{\text {th }}$ percentile values of wave parameters were calculated for all hourly times within that class.

Wave model hindcast results improve through the use of data assimilation, either through direct use of wave measurements or through use of forcing wind models that assimilate data (Bidlot and others, 2002; Chen and others, 2004); for example, the operational NWW3 forecast uses winds from the Global Data Assimilation System (GDAS; Derber and others, 1991; Tolman and others, 2002). Surface ocean wind speed data were assimilated into the CFSR model when possible; however, data were only available for portions of the 30-year record and varied in source (see Saha and others, 2010, for more information). No wave data were assimilated in the NWW3 hindcast. To improve prediction accuracy, the offset between CFSR-simulated wave values for each class and observations at wave buoys were 
Table 1. Difference between CFSR model simulated and observed non-tidal surge, significant wave height, and dominant wave period. Observed data are from six wave buoy and tide gage locations from North Carolina to Maine with records ranging from 9 to 31 years.

[m, meter; stdev, standard deviation; s, second]

\begin{tabular}{|c|c|c|c|c|c|c|c|c|}
\hline \multicolumn{9}{|c|}{ Non-tidal Surge (m) } \\
\hline \multirow{3}{*}{ Location } & \multirow{3}{*}{ Tide Station } & \multirow{3}{*}{ Record time period } & \multicolumn{6}{|c|}{ Nor'easter Class } \\
\hline & & & \multicolumn{3}{|c|}{ Observed mean } & \multicolumn{3}{|c|}{ Error } \\
\hline & & & 1 & 2 & 3 & 1 & 2 & 3 \\
\hline Duck, NC & 8651370 & $1979-2009$ & 0.92 & 1.06 & 1.29 & 0.51 & 0.61 & 0.77 \\
\hline Ocean City, MD & 8570283 & $1997-2009$ & 0.81 & 0.90 & 1.21 & 0.60 & 0.67 & 0.89 \\
\hline Sandy Hook, NJ & 8531680 & 1979-2009 & 1.32 & 2.24 & 2.55 & 0.63 & 1.47 & 1.57 \\
\hline Montauk, NY & 8510560 & 1979-2009 & 0.75 & 0.90 & 1.38 & 0.54 & 0.65 & 1.00 \\
\hline Boston, MA & 8443970 & 1979-2009 & 1.86 & 2.01 & 2.43 & 0.48 & 0.57 & 0.84 \\
\hline Portland, ME & 8418150 & 1979-2009 & 1.77 & 1.90 & 2.16 & 0.42 & 0.51 & 0.62 \\
\hline mean & & & 1.24 & 1.50 & 1.84 & 0.53 & 0.75 & 0.95 \\
\hline stdev & & & 0.45 & 0.56 & 0.56 & 0.07 & 0.33 & 0.30 \\
\hline
\end{tabular}

\begin{tabular}{|c|c|c|c|c|c|c|c|c|}
\hline \multicolumn{9}{|c|}{ Significant Wave Height (m) } \\
\hline \multirow{3}{*}{ Location } & \multirow{3}{*}{ Wave Buoy } & \multirow{3}{*}{ Record time period } & \multicolumn{6}{|c|}{ Nor'easter Class } \\
\hline & & & \multicolumn{3}{|c|}{ Observed mean } & \multicolumn{3}{|c|}{ Error } \\
\hline & & & 1 & 2 & 3 & 1 & 2 & 3 \\
\hline Duck, NC & 44014 & $1990-2009$ & 3.23 & 4.46 & 6.70 & -0.18 & 0.07 & 0.77 \\
\hline Ocean City, MD & 44009 & 1984-2009 & 2.64 & 3.90 & 6.41 & 0.17 & 0.42 & 1.61 \\
\hline Sandy Hook, NJ & 44025 & $1975-2009$ & 2.69 & 3.84 & 6.57 & 0.14 & 0.20 & 1.22 \\
\hline Montauk, NY & 44017 & 2002-2009 & 3.10 & 4.09 & 5.91 & 0.33 & 0.12 & 0.07 \\
\hline Boston, MA & 44013 & 1984-2009 & 2.90 & 4.03 & 7.07 & 0.51 & 0.80 & 1.83 \\
\hline Portland, ME & 44007 & $1982-2009$ & 3.00 & 4.30 & 6.30 & 0.67 & 0.98 & 1.61 \\
\hline \multicolumn{2}{|l|}{ mean } & & 2.93 & 4.10 & 6.49 & 0.27 & 0.43 & 1.19 \\
\hline \multicolumn{2}{|l|}{ stdev } & & 0.21 & 0.22 & 0.36 & 0.27 & 0.35 & 0.60 \\
\hline \multicolumn{9}{|c|}{ Dominant Wave Period (s) } \\
\hline & & & \multicolumn{6}{|c|}{ Nor'easter Class } \\
\hline \multirow{2}{*}{ Location } & \multirow{2}{*}{ Wave Buoy } & \multirow{2}{*}{ Record time period } & \multicolumn{3}{|c|}{ Observed mean } & \multicolumn{3}{|c|}{ Error } \\
\hline & & & 1 & 2 & 3 & 1 & 2 & 3 \\
\hline Duck, NC & 44014 & $1990-2009$ & 16.67 & 16.70 & 16.70 & 2.42 & 2.15 & 3.03 \\
\hline Ocean City, MD & 44009 & 1984-2009 & 16.67 & 16.67 & 14.30 & 2.48 & 2.42 & 0.55 \\
\hline Sandy Hook, NJ & 44025 & $1975-2009$ & 14.30 & 14.30 & 14.30 & -0.47 & 0.54 & 0.78 \\
\hline Montauk, NY & 44017 & $2002-2009$ & 14.81 & 14.81 & 13.79 & 1.08 & 1.18 & 0.43 \\
\hline Boston, MA & 44013 & 1984-2009 & 16.67 & 16.67 & 16.67 & 0.17 & 1.26 & 1.82 \\
\hline Portland, ME & 44007 & $1982-2009$ & 16.00 & 16.67 & 14.81 & -0.39 & 0.90 & -0.82 \\
\hline mean & & & 15.85 & 15.97 & 15.10 & 0.88 & 1.41 & 0.97 \\
\hline stdev & & & 0.96 & 1.01 & 1.16 & 1.22 & 0.67 & 1.20 \\
\hline
\end{tabular}


calculated for each storm class and added to the predicted values. The CFSR-simulated wave height and period were lower than the wave buoy observed wave height and period at the six sites along the Atlantic coast. The mean offsets were $0.27 \mathrm{~m}, 0.43 \mathrm{~m}$, and $1.19 \mathrm{~m}$ for significant wave height and 0.88 seconds $(\mathrm{s}), 1.41 \mathrm{~s}$, and $0.97 \mathrm{~s}$ for dominant wave period for storm classes $1-3$, respectively (table 1). The mean offset for each parameter and storm class was added to the $99^{\text {th }}$ percentile wave height and period data at each alongshore location.

Maximum $H_{s}$ at the $20 \mathrm{~m}$ isobath for class 1-3 nor'easters varied along the Atlantic coast (fig. 11). The resulting maximum $H_{s}$ at the $20 \mathrm{~m}$ isobath for a class 1 nor'easter typically ranged from about $1.6 \mathrm{~m}$ to about $3.4 \mathrm{~m}$. Maximum $H_{s}$ at the $20 \mathrm{~m}$ isobath for a class 3 nor'easter typically ranged from about $3.6 \mathrm{~m}$ to about $7.1 \mathrm{~m}$. Maximum $T_{p}$ at the $20 \mathrm{~m}$ isobath ranged from 13.75 to $18.6 \mathrm{~s}$ and was somewhat similar for all nor'easter classes.

\subsubsection{Wave Setup and Swash}

Wave setup and swash, the wave-induced components of total shoreline water levels, were parameterized using modeled wave conditions and beach slope $\left(\beta_{m}\right)$ estimated from the lidar observations (Stockdon and others, 2006). Setup, required in the calculation of both mean $\left(\eta_{50}\right)$ and extreme $\left(\eta_{98}\right)$ nor'easter-induced water levels, was parameterized as

$$
\eta_{\text {setup }}=0.35 \beta_{m}\left(H_{0} L_{0}\right)^{1 / 2}
$$

where $L_{0}$ is the offshore wave length $\left(L_{0}=g T_{p}^{2} / 2 \pi\right)$, and $H_{0}$ is the offshore wave height, taken from model output (adjusted as previously described) at the $20 \mathrm{~m}$ isobath. Wave swash, $S$, is the time-varying component of water levels at the shoreline and part of the calculation of extreme $\left(\eta_{98}\right)$ nor' easterinduced water levels. Wave swash is parameterized as

$$
S=\left[H_{0} L_{0}\left(0.563 \beta_{m}^{2}+0.005\right)\right]^{1 / 2}
$$

Combining equations 4 and 5 with modeled $\eta_{\text {surge }}$ ' provided estimates of nor'easter-induced mean and maximum water levels (equations 1 and 2).

\subsection{Probability of Coastal Change}

Probabilities of coastal change are based on estimating the likelihood that the beach system will experience erosion and deposition patterns consistent with the collision, overwash, or inundation regimes. Uncertainties in the probability estimates include those associated with measurements of topographic elevation (for example, lidar positional and interpolation uncertainties) and those associated with predicting wave runup elevations (for example, uncertainty in beach slope, and CFSR and NWW3 model error).

The probabilities of collision, overwash, and inundation were calculated using distributions of morphologic and hydrodynamic parameters extracted from 1-km sections of coast. Hydrodynamic and morphologic data were co-located alongshore using a common reference line (the 20-year high water line [HWL] shoreline [Ruggiero and List, 2009]). Morphologic features, $z_{c}, z_{t}$, and $\beta_{m}$, were interpolated 


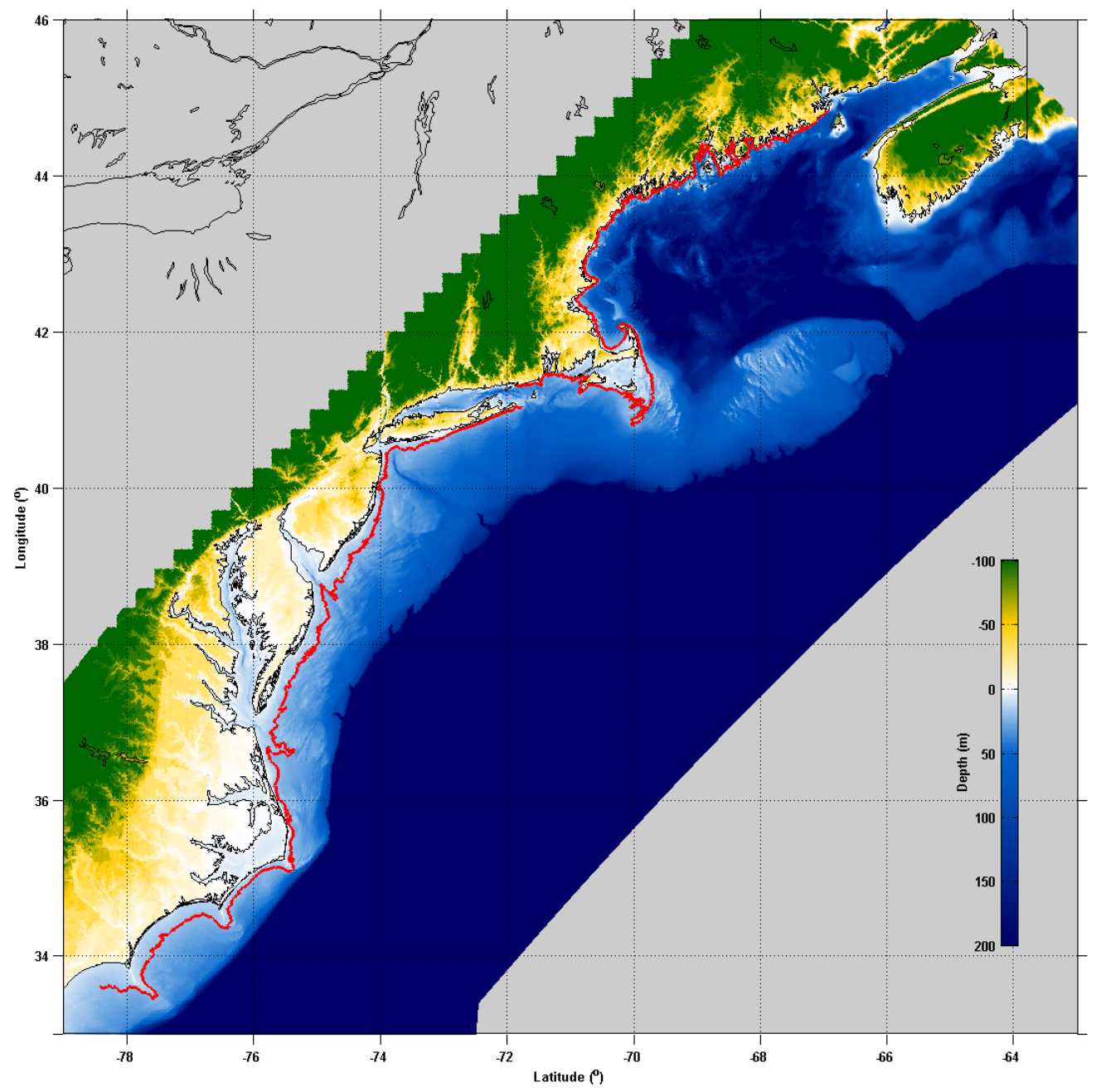

Figure 10. Nor'easter analysis study area along the Atlantic coast from North Carolina to Maine. The bathymetry and topography of the study area are shown by the color bar; the 20 meter isobath along the study area is shown in red, and the coastline is shown in black. Abbreviation: $m$, meter.

to the reference line and smoothed using a Hanning window with a full width of $2 \mathrm{~km}$. Each interpolated, smoothed value of $\left(x_{c}, z_{c}\right),\left(x_{t}, z_{t}\right)$, and $\beta_{m}$ was assigned a RMS error calculated from the scatter of the data in the smoothing window (fig. 12, top). The variables were represented with a normal distribution of values at the location of each 1-km section of coast using the interpolated value as the mean and the RMS error as the standard deviation (fig. 12, bottom). This analysis produced mean and standard deviations for both the hydrodynamic and the morphologic variables.

Using the statistical distribution of the input values at each alongshore location, the probability, $p$, that the total water level exceeds the dune crest or toe elevation threshold for a particular storm regime is calculated from the normal cumulative distribution function

$$
p=\frac{1}{\sigma \sqrt{2 \pi}} \int_{0}^{\infty} e^{\frac{-(t-\mu)^{2}}{2 \sigma^{2}}} d t
$$




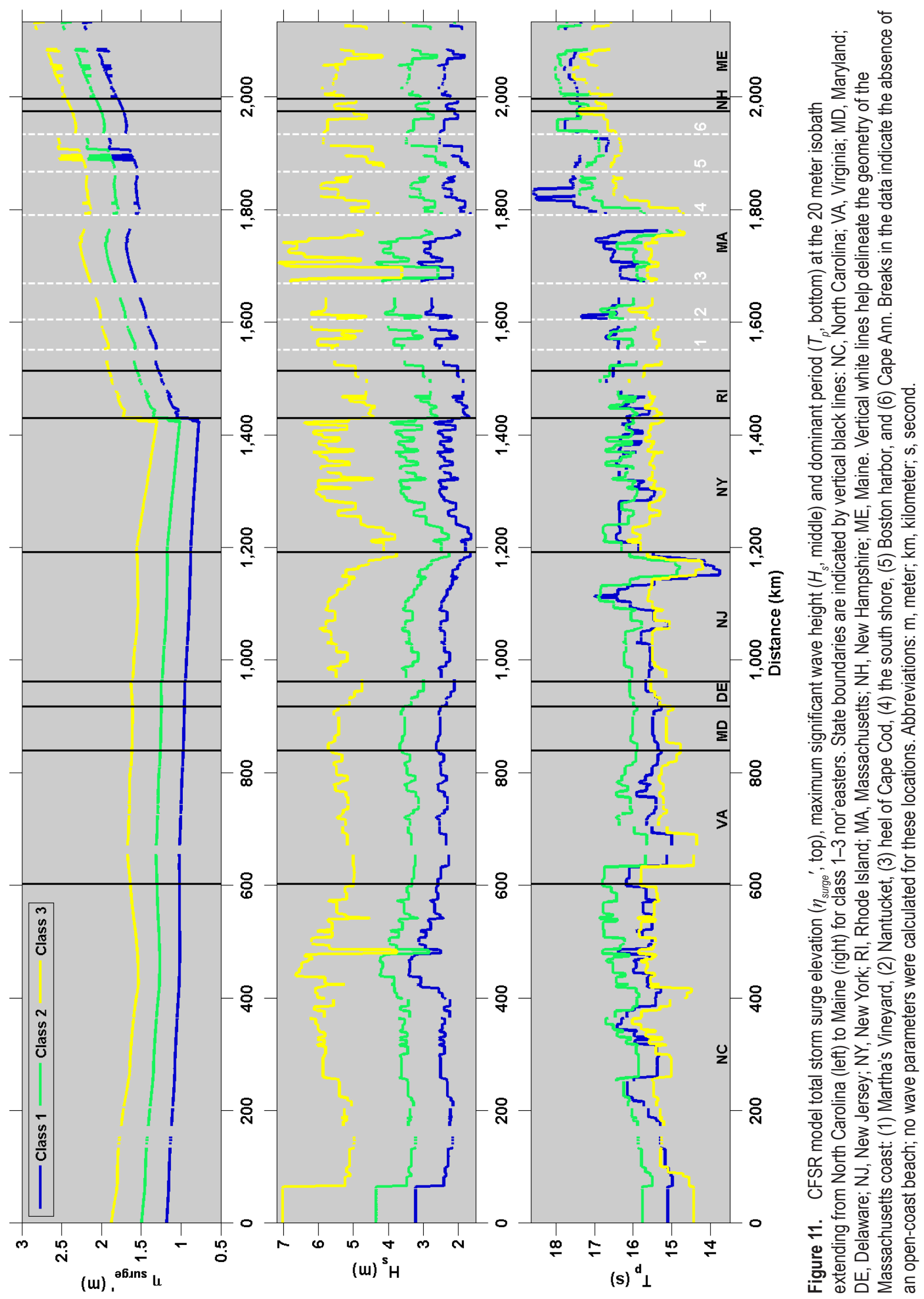


where $\mu$ is the mean difference between either the mean (inundation) or extreme (collision, overwash) water levels and either the dune toe (collision) or dune crest (overwash, inundation). The variance of the difference, $\sigma^{2}$, is the sum of the variances of the inputs. Thus, the probabilities of each storm-impact regime are calculated as

- Collision: $p_{c}=$ probability $\left(\left[\eta_{98}-z_{t}\right]>0\right)$

- Overwash: $p_{o}=$ probability $\left(\left[\eta_{98}-z_{c}\right]>0\right)$

- Inundation: $p_{i}=$ probability $\left(\left[\eta_{50}-z_{c}\right]>0\right)$

For example, figure 12 shows the cumulative distribution of $\left(\eta_{98}-z_{c}\right)$ for a 1-km section of coast for a category 1 hurricane. The probability that this value exceeds zero defines the likelihood that overwash will occur at this location.

\section{Results}

\subsection{Coastal Morphology}

A vast majority of the shoreline along the mid- and northeast Atlantic coast (see fig. 6 for delineations of these regions) consists of sandy beaches; however, the coastal morphology includes gravel and mixed sediment beaches, as well as bluff-backed beaches and rocky coast. (See Section 4.3 for a detailed discussion of regional beach morphology.) For this study, rocky coasts were omitted from the analysis because the models do not apply.

For a detailed summary of alongshore dune morphologies, see Stockdon and others (2013), Doran and others (2013), and Birchler and others (2014). The morphology along the northeast coast used by Birchler and others (2014) was used in the current analysis. The morphology along the North Carolina coast used by Stockdon and others (2013) also was used in the current analysis, with the exception of locations that were updated after Hurricane Sandy made landfall in October 2012 (see fig. 6). The mean dune crest height along the mid-Atlantic coast was lowered by $0.2 \mathrm{~m}$ between the 2010 and 2012 lidar surveys; the mean dune crest heights in Maryland and New Jersey were lowered by $0.5 \mathrm{~m}$, and the mean dune crest height in New York was lowered by $0.75 \mathrm{~m}$. The mean dune toe height in the mid-Atlantic decreased by $0.1 \mathrm{~m}$, but the response varied alongshore. Because Hurricane Sandy significantly altered the coast in some regions, differences in estimated probabilities of coastal change between the Doran and others (2013) report for hurricanes and the current report for nor'easters result from both differences in estimated storm parameters for the two types of systems and changes in morphology.

Dune morphologies along the mid- and northeast Atlantic coast vary over both short and long (regional) spatial scales (table 2). The distribution of dune crest and toe heights for the entire study area is shown in figure 13 (top, middle), and the distribution for individual States is shown in figure 14. Local spatial variability tends to scale with dune elevation; locations with higher mean elevations often exhibit greater spatial variability (fig. 15).

The highest dunes ( $z_{c}$ in excess of $10 \mathrm{~m}$, not including bluff-backed coasts) are located in Massachusetts at the northern end of Cape Cod (figs. 14, 16); however, variability is high for the State of Massachusetts $\left(\mu z_{c}=5.29 \mathrm{~m} ; \sigma z_{c}=2.25 \mathrm{~m}\right)$. The lowest elevations are found in Virginia, where $\mu z_{c}=3.10 \mathrm{~m}$ and $\sigma z_{c}=1.67 \mathrm{~m}$. 

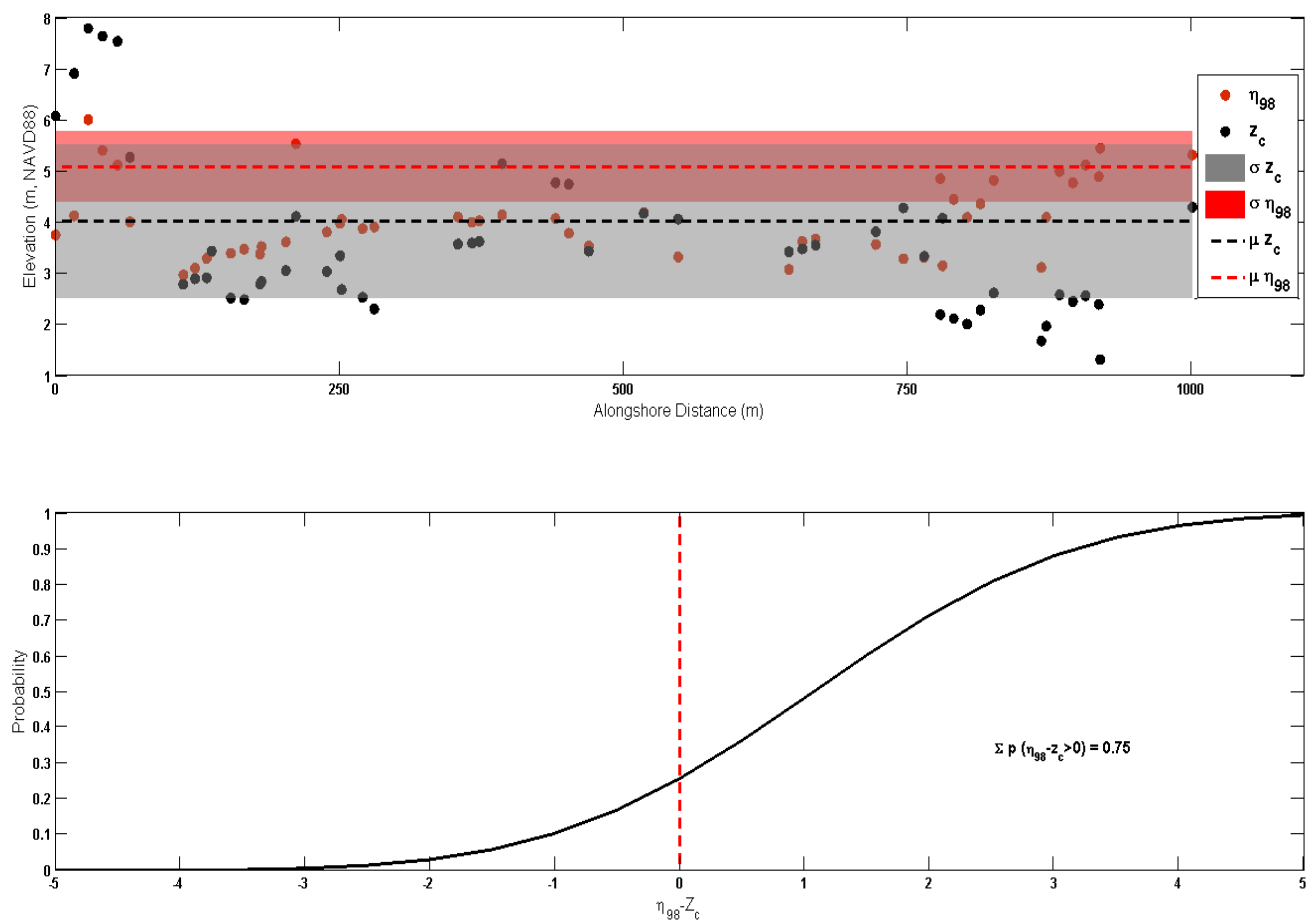

Figure 12. Maximum shoreline water level $\left(\eta_{98}\right)$ for a category 1 hurricane and raw and smoothed dune crest elevation $\left(z_{c}\right)$ for a 1-kilometer alongshore section (top). Shaded areas indicate the RMS error for dune crest elevation and maximum water level $\left(\sigma z_{c}\right.$ and $\left.\sigma \eta_{98}\right)$ about the mean value $\left(\mu z_{c}\right.$ and $\left.\mu \eta_{98}\right)$ within the section. Cumulative probability distribution of points in the top panel, $p\left(\eta_{98}-z_{c}\right)$ where the sum of $p$ over the range $\left(\eta_{98}-z_{c}\right)>0$ defines the probability of overwash (bottom). Abbreviation: m, meter; NAVD88, North American Vertical Datum of 1988.

Part of the beaches along Long Island, New York, the islands of Martha's Vineyard and Nantucket in Massachusetts, and Cape Cod, Massachusetts, are backed by sandy bluffs, which range in height from 10 to $30 \mathrm{~m}$ on Long Island, 10 to $40 \mathrm{~m}$ on Martha's Vineyard and Nantucket, and 10 to $55 \mathrm{~m}$ at Cape Cod (see fig. 16). Although it is extremely unlikely for the bluff crest to be subjected to overwash or inundation, the base of the bluff (dune toe) may be prone to erosion during extreme water levels. The locations of the bluffed beaches are shown in graphical format in figure 16.

Although also spatially variable, mean beach slope along the mid- and northeast Atlantic coast ranges from low to intermediate $\left(\mu \beta_{m}=0.059 ; \sigma \beta_{m}=0.037\right.$; figs. 13, 17). The lowest slopes are located along the Virginia coast $\left(\mu \beta_{m}=0.036 ; \sigma \beta_{m}=0.027\right)$. The steepest slopes are present along the New Hampshire coast $\left(\mu \beta_{m}=0.131\right)$; however, the standard deviation was also greatest along the New Hampshire coast $\left(\sigma \beta_{m}=0.073\right)$, indicating a wide range of slopes. The steepest slopes in New Hampshire $\left(\beta_{m}>0.15\right)$ are due to a narrow beach, fronting revetment systems designed to protect coastal infrastructure.

\subsection{Nor'easter-Induced Water Levels}

The spatial variability of nor'easter-induced water levels can be attributed to both hydrodynamics and beach morphology. Variability of $H_{s}$ at $h=20 \mathrm{~m}$ within a single storm class, due to local bathymetry, dissipation from bottom friction, regional variation in storm patterns (prevailing tracks and intensities), and coastal geometry effects (such as exposure to the open ocean along the Mid-Atlantic Bight, 
Table 2. Mean elevation of dune crest $\left(z_{c}\right)$, dune toe $\left(z_{t}\right)$, and mean beach slope $\left(\beta_{m}\right)$ for the sandy beaches along the northeast Atlantic coast.

[Standard deviation is given in parentheses. $\mathrm{m}$, meter]

\begin{tabular}{llccc}
\hline \multicolumn{1}{c}{ State/region } & $\mathbf{z}_{c}[\mathrm{~m}]$ & $\mathbf{z}_{t}[\mathrm{~m}]$ & $\boldsymbol{\beta}_{m}$ & $\begin{array}{c}\text { Survey date } \\
\text { [month/year] }\end{array}$ \\
\hline U.S. mid- and northeast Atlantic coast & $4.36(1.78)$ & $2.53(0.88)$ & $0.059(0.037)$ & $5 / 2010,11 / 2012$ \\
North Carolina & $4.29(1.56)$ & $2.46(0.77)$ & $0.056(0.024)$ & $11 / 2012$ \\
Virginia & $3.10(1.67)$ & $1.77(0.62)$ & $0.036(0.027)$ & $11 / 2012$ \\
Maryland & $3.36(0.96)$ & $2.10(0.64)$ & $0.032(0.016)$ & $11 / 2012$ \\
Delaware & $4.99(0.87)$ & $3.24(0.48)$ & $0.047(0.012)$ & $11 / 2012$ \\
New Jersey & $4.34(1.68)$ & $2.92(1.04)$ & $0.044(0.023)$ & $11 / 2012$ \\
New York & $4.76(1.56)$ & $2.74(0.95)$ & $0.052(0.033)$ & $5 / 2010$ \\
Rhode Island & $4.09(0.85)$ & $2.15(0.40)$ & $0.096(0.041)$ & $5 / 2010,11 / 2012$ \\
Massachusetts & $5.29(2.25)$ & $2.79(0.90)$ & $0.087(0.042)$ & $5 / 2010$ \\
New Hampshire & $4.49(0.95)$ & $2.51(0.35)$ & $0.131(0.073)$ & $5 / 2010$ \\
Maine & $4.45(0.96)$ & $2.43(0.45)$ & $0.093(0.038)$ & \\
\hline
\end{tabular}
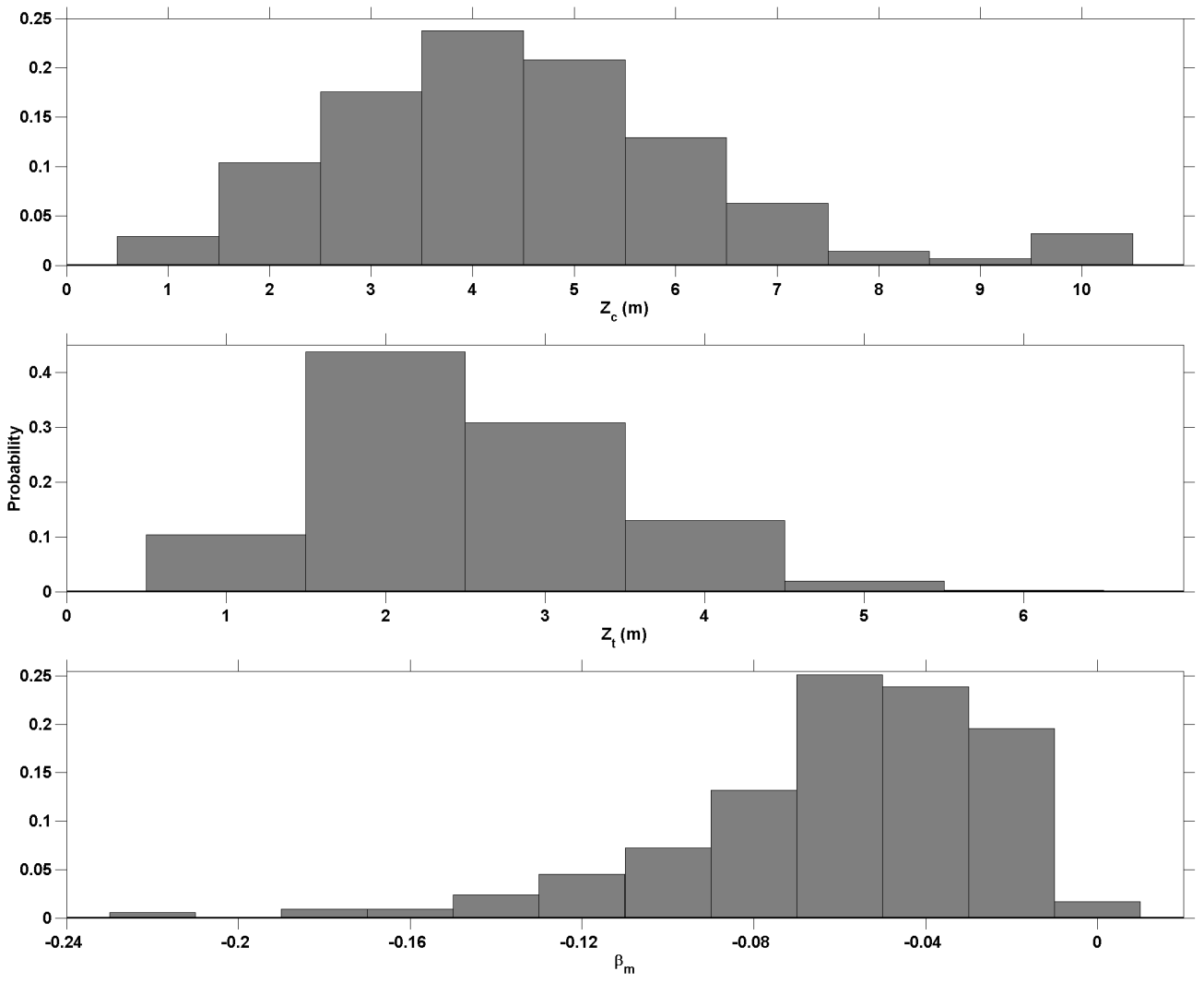

Figure 13. Distributions of dune crest elevation $\left(z_{c}\right.$, top), dune toe elevation $\left(z_{t}\right.$, middle), and mean beach slope $\left(\beta_{m}\right.$, bottom) for the mid- and northeast Atlantic sandy coastlines. Note: Some dune crest heights extend above $10 \mathrm{~m}$. Abbreviation: $\mathrm{m}$, meter. 

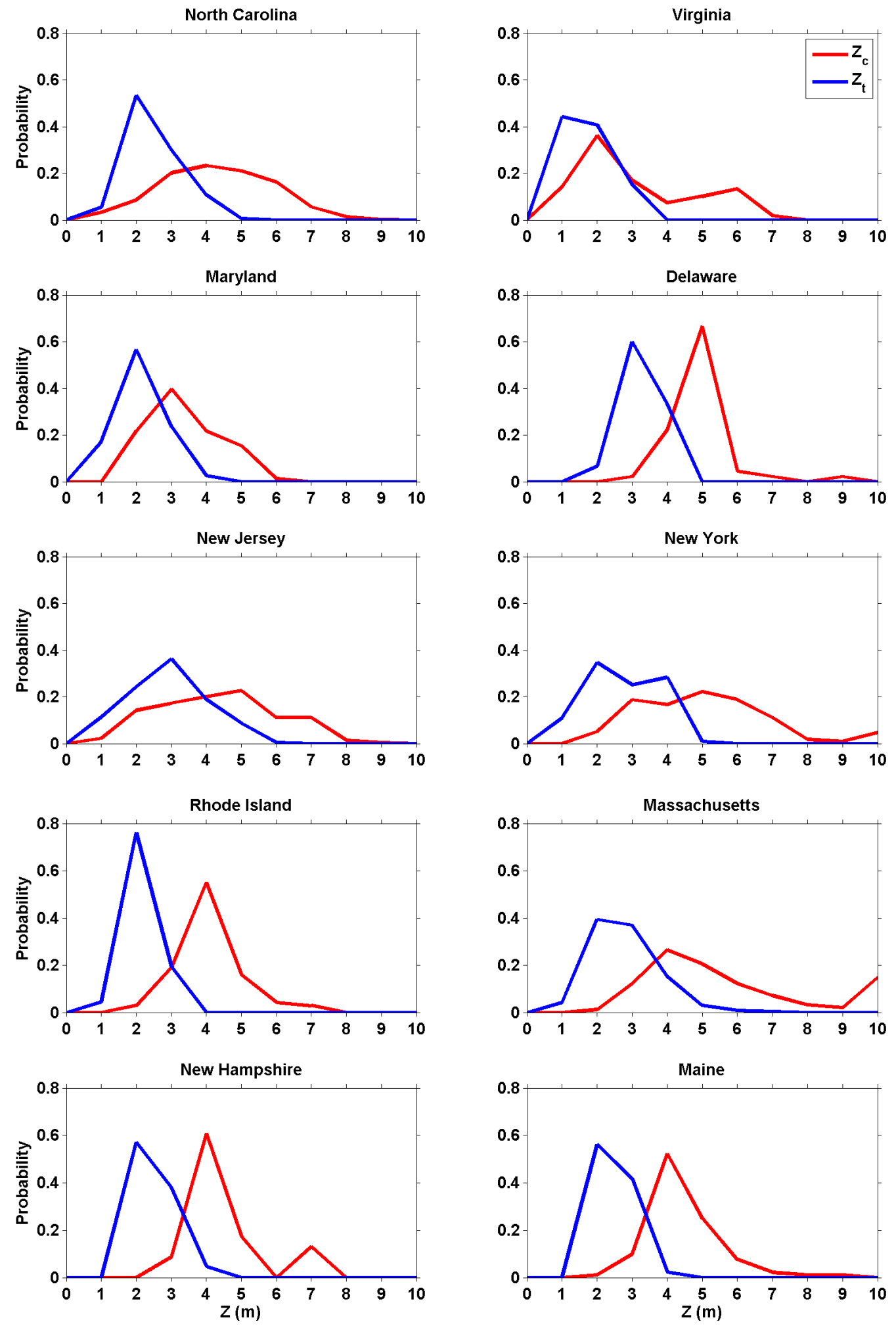

Figure 14. Distribution of dune crest $\left(z_{c}\right)$ and dune toe $\left(z_{t}\right)$ elevations for North Carolina, Virginia, Maryland, Delaware, New Jersey, New York, Rhode Island, Massachusetts, New Hampshire, and Maine.

Note: Dune crest height in New York and Massachusetts extends above 10 m. Abbreviation: m, meter. 


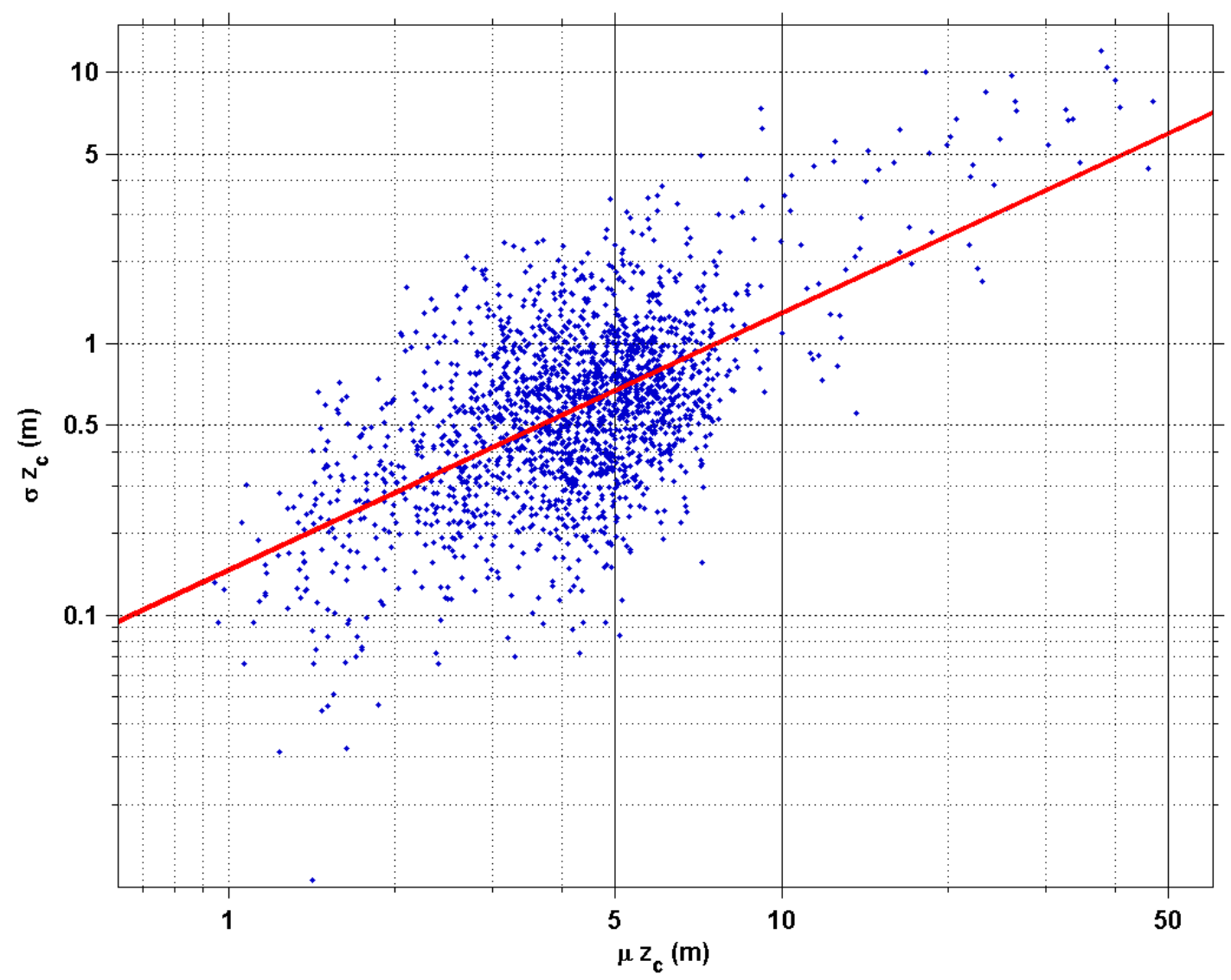

Figure 15. Mean dune crest elevation $\left(\mu z_{c}\right)$ for 1-kilometer sections of mid- and northeast Atlantic coastline compared to the standard deviation $\left(\sigma z_{c}\right)$ in those sections. The red line indicates the best fit line between the two variables. $r^{2}=0.58, N=1,891$. Note: Data are plotted on a log-log scale. Abbreviation: $m$, meter.

as opposed to the semi-confined Gulf of Maine north of Cape Cod), leads to corresponding alongshore differences in $\eta_{98}$ and $\eta_{50^{\circ}}$. Some of the largest waves $\left(H_{s}=7 \mathrm{~m}\right)$ were located offshore of Cape Cod, north of Eastham, Massachusetts (fig. 11; $\mathrm{x}=1,705 \mathrm{~km}$ alongshore). Because of the narrow shelf, wave breaking and bottom dissipation act over very short distances before reaching the $20 \mathrm{~m}$ isobath, allowing larger waves to make it to the nearshore. However, for the beaches used in this analysis, variability of $H_{s}$ over a $20 \mathrm{~km}$ alongshore extent within a single class is generally less than $1 \mathrm{~m}$; variability ranges from 1.6 to $3.4 \mathrm{~m}$ along the coast for a class 1 storm, and standard deviation of $H_{s}$ ranges from $0.35 \mathrm{~m}$ for a class 1 storm to $0.65 \mathrm{~m}$ for a class 3 storm (table 3 ).

For class 1-3 storm conditions, average wave runup $\left(\eta_{R 2}\right)$ along the mid- and northeast Atlantic coast is 2 to $3 \mathrm{~m}$. Regional variability in runup is due, in part, to spatial variations in beach slope, because the wave-driven components of shoreline water levels, $\eta_{\text {setup }}$ and $S$, are dependent on both input wave conditions and local slopes (equations 4 and 5). For similar input wave conditions, steeper beach slopes result in higher total runup elevations (equations 4 and 5). Along the northeast Atlantic coast, mean beach slope, $\mu \beta_{m}$, is 28 percent higher than in the mid-Atlantic, leading to 56, 50, and 54 percent higher $\eta_{R 2}$ in the northeast region for class 1-3 storms, respectively. Within a region, smaller-scale variability can also be attributed to beach slope. For example, the statewide average class $3 \eta_{R 2}$ is $1.2 \mathrm{~m}$ higher for New Hampshire than for Massachusetts despite the fact that mean wave height is $0.21 \mathrm{~m}$ 


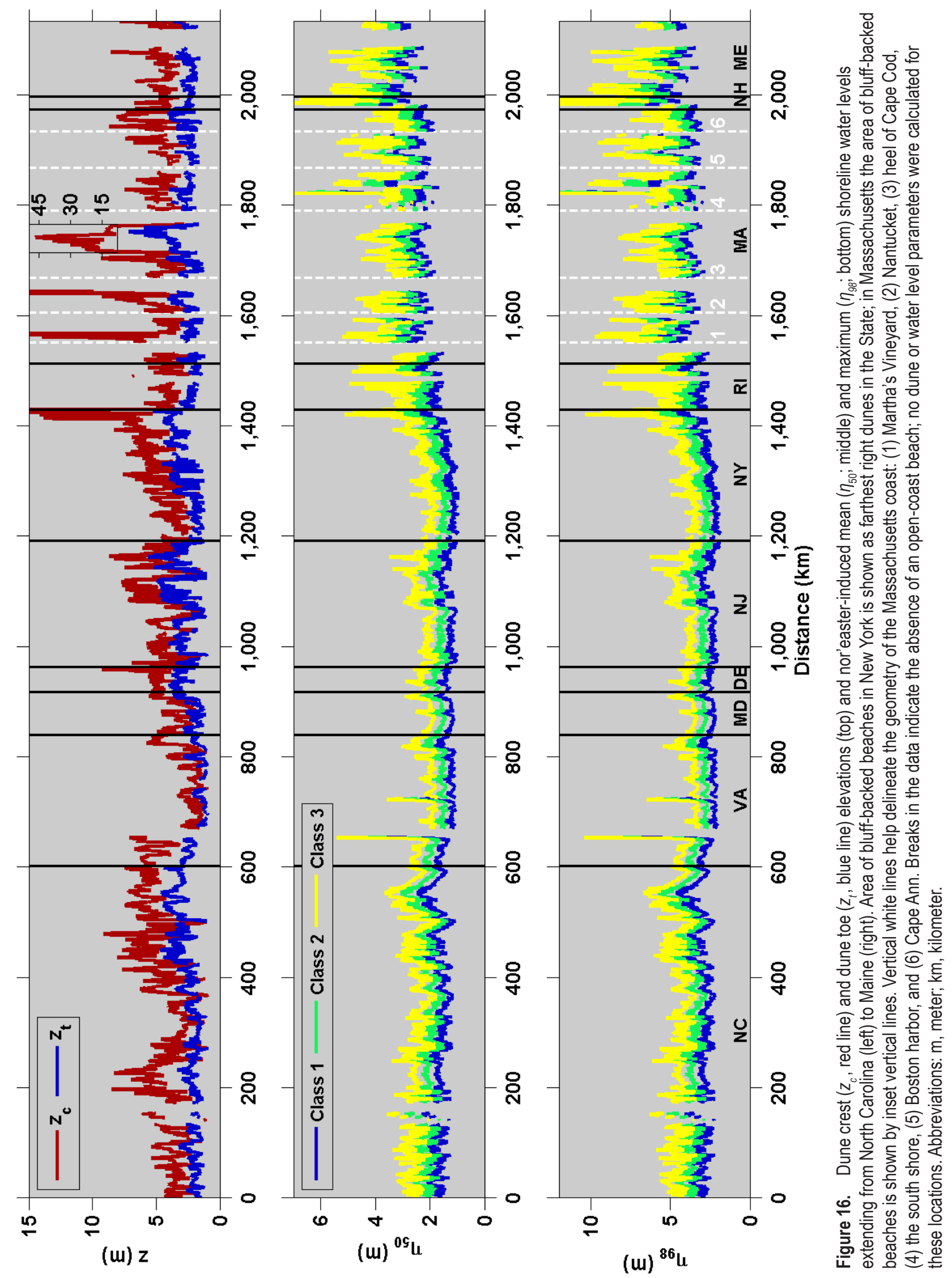



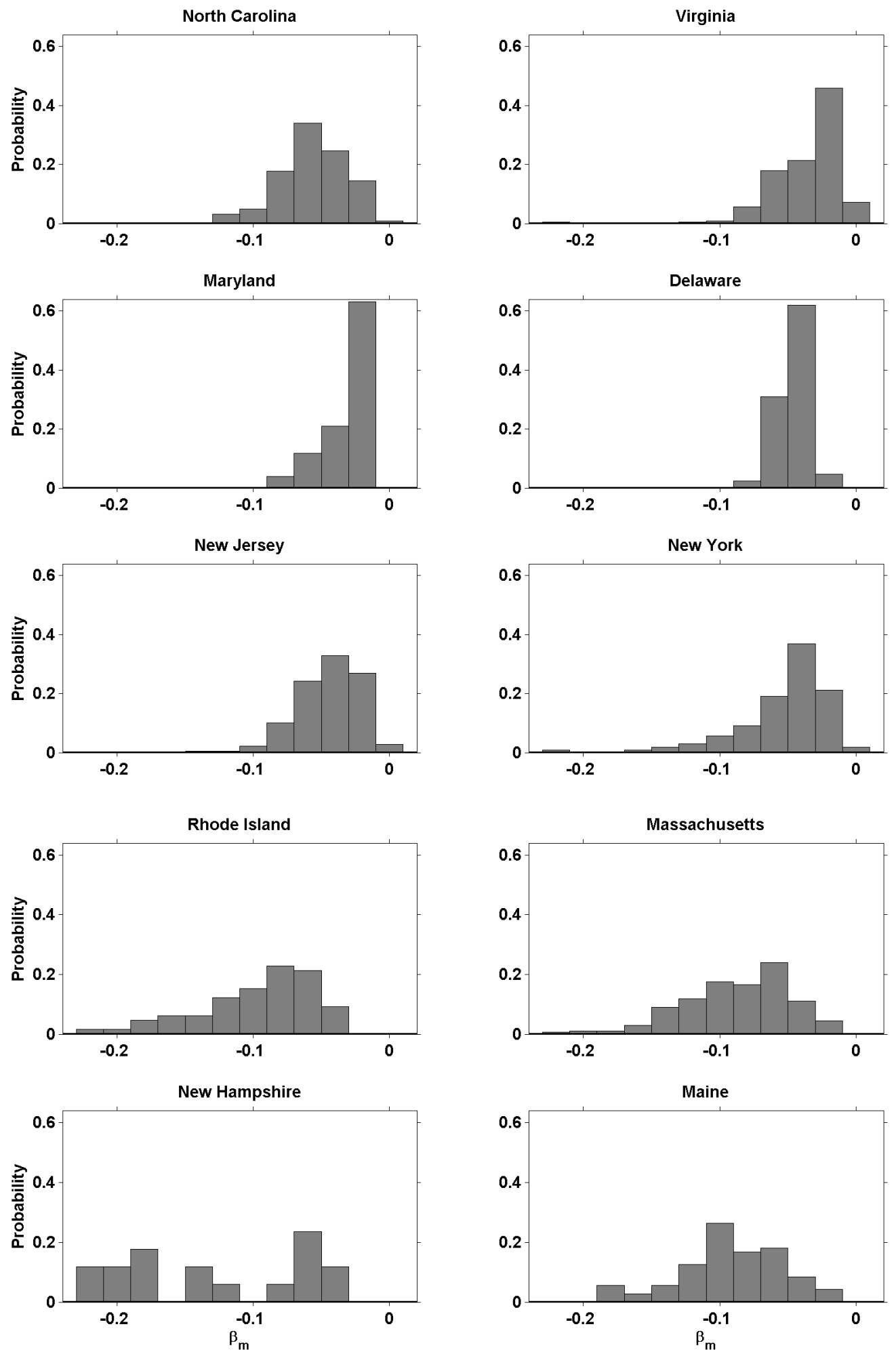

Figure 17. Distributions of mean beach slope $\left(\beta_{m}\right)$ for North Carolina, Virginia, Maryland, Delaware, New Jersey, New York, Rhode Island, Massachusetts, New Hampshire, and Maine. 
lower. The higher wave runup in New Hampshire is due to the steeper beach slope $\left(\mu \beta_{m}=0.131\right) \mathrm{com}-$ pared to that in Massachusetts $\left(\mu \beta_{m}=0.087\right)$.

The analysis for the mid- and northeast Atlantic coast demonstrated the relative importance of waves with respect to storm surge for extratropical systems, consistent with previous observations of weaker hurricanes. Wave-driven components represent 63 percent of the total nor'easter-induced water levels; the remaining 37 percent is attributed to storm surge (table 3 ). The relative contribution of wave-driven components is not dependent on nor'easter class.

\subsection{Probability of Coastal Change}

Probabilities of coastal change for the lowest class nor'easter show that beaches along the mid- and northeast Atlantic coast are vulnerable to erosion (fig. 18). For the impact of a class 1 nor'easter, 41 percent of sandy beaches are very likely (probability $>0.9$; definition based on guidance from the Intergovernmental Panel on Climate Change [IPCC] [Cubasch and others, 2013]) to experience dune erosion due to collision, and 9 percent of the coastal areas are vulnerable to overwash (table 4). Inundation of the beach and dune system is not expected in this region during a class 1 storm. For a class 3 nor'easter, 83 percent of mid- and northeast Atlantic sandy beaches are very likely to experience dune erosion due to collision, 32 percent of beaches are very likely to experience overwash, and the percentage of beaches that are very likely to be inundated increases to 6 percent (table 4 ).

Beaches in the northeast are more vulnerable to coastal change during nor'easters than those in the mid-Atlantic region. Although the average dune elevation in the northeast is higher than along the mid-Atlantic coast, beaches are steeper (as previously mentioned), and the maximum storm water levels are higher in this region than in the mid-Atlantic. For a class 3 storm, New Hampshire and Maine were likely $(p>0.66)$ to experience overwash; Virginia, Rhode Island, and Massachusetts were about as likely as not $(0.33<p<0.66)$ to experience overwash. All States were unlikely or very unlikely to experience inundation for a class 3 storm.

Spatial variability exists over smaller spatial scales, on the order of kilometers, in areas with complex dune fields or extensive three-dimensional beach morphology. The mix of low and high dunes along the northeast Atlantic coast (fig. 16) leads to a complicated mix of nor'easter-induced erosion hazards within each State and across the entire region. The smaller scale variability (alongshore spacing of $1 \mathrm{~km}$ ) for a specific area can be examined using interactive maps that are available online. The probability of each mode of coastal change for class 1-3, as well as supporting morphology and water level data, are available online (http://coastal.er.usgs.gov/hurricanes/assessments/scenario-based.php and http://marine.usgs.gov/coastalchangehazardsportal/).

Table 3. Mean input wind speed, significant wave height $\left(H_{s}\right)$, wave period $\left(T_{p}\right)$, modeled setup $\left(\eta_{\text {setup }}\right)$, runup $\left(\eta_{R 2}\right)$, and storm surge $\left(\eta_{\text {surge }}\right)$ for class 1-3 nor'easters.

[Standard deviation is given in parentheses. $\mathrm{m} / \mathrm{s}$, meters per second; $\mathrm{m}$, meter; $\mathrm{s}$, second]

\begin{tabular}{ccccccc}
\hline $\begin{array}{c}\text { Nor'easter } \\
\text { intensity class }\end{array}$ & $\begin{array}{c}\text { Wind } \\
\text { speed }[\mathrm{m} / \mathbf{s}]\end{array}$ & $\boldsymbol{H}_{\mathbf{s}}[\mathrm{m}]$ & $\boldsymbol{T}_{p}[\mathrm{~s}]$ & $\boldsymbol{\eta}_{\text {setup }}[\mathrm{m}]$ & $\boldsymbol{\eta}_{R 2}[\mathrm{~m}]$ & $\boldsymbol{\eta}_{\text {surge }}{ }^{\prime}[\mathrm{m}]$ \\
\hline 1 & $6-12$ & $2.40(0.35)$ & $15.98(0.79)$ & $0.66(0.43)$ & $2.05(0.84)$ & $1.15(0.32)$ \\
2 & $12-18$ & $3.37(0.42)$ & $16.30(0.58)$ & $0.79(0.51)$ & $2.48(0.98)$ & $1.43(0.31)$ \\
3 & $>18$ & $5.42(0.65)$ & $15.49(0.62)$ & $0.95(0.62)$ & $2.99(1.21)$ & $1.77(0.32)$ \\
\hline
\end{tabular}




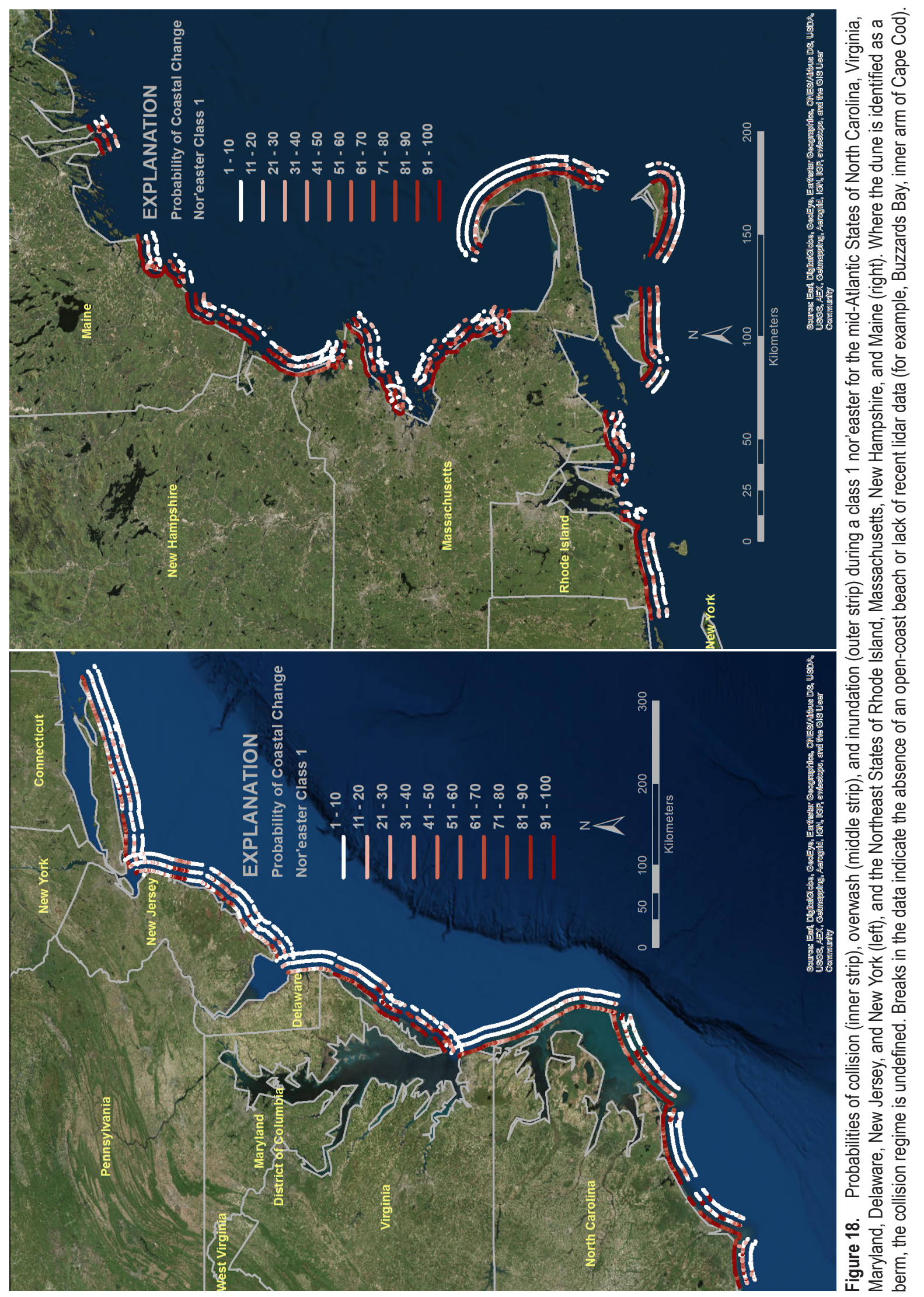


Table 4. Percentage of coast very likely $(p>0.9)$ to experience erosion associated with collision, overwash, and inundation during class $1-3$ nor'easters.

\begin{tabular}{|c|c|c|c|}
\hline & \multicolumn{3}{|c|}{ Nor'easter intensity class } \\
\hline & 1 & 2 & 3 \\
\hline \multicolumn{4}{|l|}{ Collision } \\
\hline U.S. mid- and northeast Atlantic & 41 & 66 & 83 \\
\hline North Carolina & 40 & 74 & 93 \\
\hline Virginia & 61 & 94 & 99 \\
\hline Maryland & 22 & 57 & 91 \\
\hline Delaware & 0 & 5 & 45 \\
\hline New Jersey & 12 & 24 & 47 \\
\hline New York & 12 & 31 & 60 \\
\hline Rhode Island & 68 & 95 & 98 \\
\hline Massachusetts & 62 & 82 & 93 \\
\hline New Hampshire & 78 & 100 & 100 \\
\hline Maine & 99 & 100 & 100 \\
\hline \multicolumn{4}{|l|}{ Overwash } \\
\hline U.S. mid- and northeast Atlantic & 9 & 18 & 32 \\
\hline North Carolina & 7 & 16 & 29 \\
\hline Virginia & 22 & 44 & 58 \\
\hline Maryland & 0 & 9 & 28 \\
\hline Delaware & 0 & 0 & 0 \\
\hline New Jersey & 6 & 10 & 17 \\
\hline New York & 0 & 2 & 7 \\
\hline Rhode Island & 5 & 18 & 47 \\
\hline Massachusetts & 7 & 19 & 36 \\
\hline New Hampshire & 28 & 50 & 67 \\
\hline Maine & 33 & 53 & 78 \\
\hline \multicolumn{4}{|l|}{ Inundation } \\
\hline U.S. mid- and northeast Atlantic coast & 1 & 2 & 6 \\
\hline North Carolina & 1 & 2 & 6 \\
\hline Virginia & 0 & 2 & 22 \\
\hline Maryland & 0 & 0 & 0 \\
\hline Delaware & 0 & 0 & 0 \\
\hline New Jersey & 0 & 2 & 4 \\
\hline New York & 0 & 0 & 0 \\
\hline Rhode Island & 0 & 2 & 2 \\
\hline Massachusetts & 0 & 0 & 2 \\
\hline New Hampshire & 0 & 11 & 17 \\
\hline Maine & 3 & 6 & 19 \\
\hline
\end{tabular}




\section{Discussion}

\subsection{Validity of Assumptions}

This analysis is based on an estimate of a worst-case scenario with respect to storm surge levels and wave heights associated with each nor'easter class, as well as impacts at high tide. In other words, probabilities are based on the assumption that each location along the coast simultaneously experiences the strongest waves and storm surge for each class of nor'easter storm, when in reality the largest waves may not correspond in time to the maximum surge or to high tide.

Waves and storm surge associated with an actual storm may be substantially different than model results indicate. The results from CFSR model data are grouped by three wind speed classes, and the $99^{\text {th }}$ percentile significant wave height, dominant wave period, and high tide and surge elevation were identified for each location and each storm class. The duration of a nor'easter can greatly influence the setup of water and the storm surge present along the coast. In the case of a long duration, class 1 or 2 nor'easter, waves and surge could be greater than expected, and the impact on the beach and dunes will be prolonged. In the case of a short duration class 3 nor'easter, the impact on the coast may be similar to a weak tropical storm - high winds, waves, and surge for a very short amount of time, but no large scale erosion.

This report compares the differences between water levels and beach topography. According to Sallenger (2000), it can be assumed that relative effects of storms are predicted on the basis of the comparison of these two quantities. This approach does not quantify potential differences due to duration, as mentioned above, as well as stabilizing effects of beaches and dunes by vegetation, sediment compaction, or other factors.

This assessment also assumes that the existing lidar-surveyed topography is up to date and accurately and synchronously reflects dune and beach morphology. Substantial changes to beach and dune morphology between the survey date and dates of future extreme storms may affect the probabilities of coastal change. It is assumed that dune elevations change relatively slowly under non-storm conditions. Changes in beach slope, which will in turn affect the elevation of wave runup, may occur more frequently as the foreshore profile adjusts to the daily wave climate. However, use of a mean beach slope (fig. 7) in this analysis provides a more temporally stable estimate of slope and hence a more consistent measure of storm-induced wave runup.

In addition, the assessment assumes that the beach and dune morphology are static during the storm, when in reality the bathymetry and topography rapidly evolve under high energy conditions. For example, dunes that experience prolonged periods of the collision regime, such as might be expected during long duration nor' easters, will very likely undergo significant erosion. Dune slumping may occur, lowering the elevation of the dune crest and potentially resulting in overwash not predicted by comparing water levels to the original topographic profile.

\subsection{Relative Importance of Waves and Storm Surge}

Nor'easter-induced coastal changes are caused by waves and surge and the interaction of these processes with coastal morphology. Averaged across the study area, waves (setup and swash) were shown to increase water levels at the shoreline by 176 percent for a class 1 storm when compared to considering storm surge alone. Using a regional average of wave height and period for a class 1 nor'easter (table 3), the predicted wave-driven component of shoreline water levels, $\eta_{R 2}$, was $2.05 \mathrm{~m}$; 
$\eta_{R 2}$ added to storm surge results in an extreme water level $0.6 \mathrm{~m}$ higher than the mean dune toe elevation $\left(z_{t}=2.53\right)$. During a class 3 storm, $\eta_{R 2}$ was $2.99 \mathrm{~m}$, high enough to reach the mean dune toe elevation, even without surge. The extreme water level, $4.8 \mathrm{~m}$, exceeds the dune crest height in nearly 60 percent of the area along the mid- and northeast Atlantic coast (table 2).

\subsection{Uncertainty Due to Coastal Morphology}

The formulations used in this analysis were developed for sandy beaches; there may be limitations with the way the model treats non-sandy beaches. The Atlantic coast has coastal morphologies including sand, gravel, and mixed sediment beaches; rocky coasts; urbanized coasts with hardened structures such as seawalls; and bluff-backed beaches. Gravel beaches are characterized by the predominant grain size having a diameter larger than 2 millimeters (Wentworth, 1922). Gravel beaches have a larger mean grain size and subsequently higher critical threshold for transport; gravel grains are less likely to be transported and eroded during storms (Soulsby and Whitehouse, 1997). Mixed sediment beaches are defined as sand or gravel beaches with boulders immediately seaward of the beach or on the beach itself; the erosion of the beach by breaking waves may be decreased, but total water levels would not be markedly affected. Because gravel beaches and mixed sediment beaches are susceptible to erosion during storms, they are included in the runup calculations. On rocky coasts, rock formations take the place of sediment grains, and there is no beach and dune system; therefore, the runup equation does not apply, and these areas are not included in the calculations for coastal erosion. Rocky coasts are prevalent in Maine and along the coast from approximately $100 \mathrm{~km}$ north to approximately $15 \mathrm{~km}$ south of Boston, Massachusetts.

Bluffed coasts are elevated platforms composed of consolidated sediments that, although more difficult to erode than uncompacted sand, are still susceptible to storm-induced coastal change. About $15 \mathrm{~km}$ of the coast along the eastern end of Long Island, New York, is backed by 10-30 m tall bluffs, about $7 \mathrm{~km}$ of coast on Martha's Vineyard and $5 \mathrm{~km}$ of coast on Nantucket are backed by $10-40 \mathrm{~m}$ tall bluffs, and a roughly $30 \mathrm{~km}$ section of the coast along Cape Cod, Massachusetts, is backed by 10-55 m tall bluffs. The dune crest in these areas was selected as the top of the bluff, and the dune toe was selected as the base of the bluff. Although overwash and inundation are not expected to occur in these areas because the top of the bluffs should not be affected by waves and surge, collision at the base of the bluff may result in erosion.

\subsection{Comparison to January 2015 Nor'easter}

The east coast of the United States was impacted by a strong nor'easter on January 26-27, 2015. The nor'easter brought a high amount of snowfall to the mid- and northeast Atlantic regions, and the coasts along eastern Massachusetts and New Hampshire were also impacted by strong winds, waves, and storm surge. This storm presented the opportunity to (1) simulate coastal vulnerability to a specific nor'easter, a capability which in the future could inform preparations and response for individual storms; and (2) benchmark the nor' easter storm class assessment results. A hindcast simulation was run to assess the vulnerability of the northeast Atlantic coast during the January 2015 nor'easter, using real-time operational model output. Tide and surge elevations were obtained from the Extratropical Surge and Tide Operational Forecast System (ESTOFS) (Funakoshi and others, 2011), and wave parameters were obtained from the 4 arc-minute operational forecast of NWW3 (Tolman, 2009). 
The mean $\eta_{R 2}$ for Massachusetts and New Hampshire for the January nor'easter was 2.64 m; mean $\eta_{\text {surge }}{ }^{\prime}$ was $2.18 \mathrm{~m} ; 57$ percent of sandy beaches were expected to experience collision; and 13 percent of sandy beaches were expected to experience overwash (fig. 19, left). For class 1, 2, and 3 nor'easters, respectively, the mean $\eta_{R 2}$ for eastern Massachusetts and New Hampshire was $2.72 \mathrm{~m}, 3.14 \mathrm{~m}$, and $3.93 \mathrm{~m}$, and the mean $\eta_{\text {surge }}$ ' was $1.65 \mathrm{~m}, 1.92 \mathrm{~m}$, and $2.27 \mathrm{~m} ; 55$ percent, 75 percent, and 90 percent of sandy beaches were expected to experience collision; and 12 percent, 22 percent, and 38 percent of sandy beaches were expected to experience overwash for class 1,2, and 3 nor'easters, respectively (fig. 19, right).

Even though sustained winds during the January 2015 storm exceeded $18 \mathrm{~m} / \mathrm{s}$, which suggests this storm would be classified as a class 3 nor'easter, the overall storm impact prediction would fall between a class 1 and 2 nor'easter with respect to the expected vulnerability of the beach and dunes. The estimated mean $\eta_{\text {surge }}$ 'value of the January nor'easter was similar to a class 3 nor'easter, but the estimated mean $\eta_{R 2}$ value of the January nor'easter was similar to a class 1 nor'easter. The mean difference between predicted storm surge for a class 3 nor'easter and the 2015 nor'easter was $10 \mathrm{~cm}$ with a standard deviation of $23 \mathrm{~cm}$; the maximum difference between the two datasets alongshore was $60 \mathrm{~cm}$. The mean difference between predicted wave runup for a class 3 nor'easter and the 2015 nor'easter was $1.31 \mathrm{~m}$ with a standard deviation of $0.71 \mathrm{~m}$; the maximum difference between the two datasets alongshore was $4.24 \mathrm{~m}$. The model presented in this report assumes that maximum values for tide, surge, wave height, and wave period coincide. Because this pattern may not occur for any given storm; it is understood that the worst-case storm for each of three nor'easter classes may overestimate the impact along the coast.

The predicted vulnerability for the January nor'easter may have been lower than the worst-case scenario because (1) the fetch of storm waves could have been limited as the storm passed close to Cape Cod, Massachusetts, then moved northeast toward Nova Scotia, Canada, and (2) the NWW3 waves could have been underestimated. The real-time NWW3 waves are forced using the Global Forecast Model compared to the CFSR winds used for the worst-case scenario; the water levels were also taken from two different sources, ESTOFS and CFSR, the error of which is unknown, and brings uncertainty into the comparison between the two datasets. We also do not know whether either the nor'easter class prediction or the forecast model is accurate to the actual storm conditions. Unfortunately there is no post-storm lidar data to compare to the model exercises here. Future data collection could be targeted to better validate the extratropical storm models. This exercise shows that a real-time assessment is possible, although the difference between the real-time assessment and the hypothetical nor'easter classification exposes areas of uncertainty between the two methods that would need to be resolved with additional applications and validation against observed conditions and coastal change.

\subsection{Assessment Updates}

The vulnerability of sandy beaches can be expected to change in the future because of variations in storm magnitude, frequency, and track; sea-level rise; and human engineering efforts that alter beach configurations and wave climates. As new observations and storm predictions become available, assessments may be revised to provide updated probabilities as well as a synthesis of how coastal vulnerability to storms changes in the future (http:/marine.usgs.gov/coastalchangehazardsportal; http://coastal.er.usgs. gov/hurricanes/assessments/scenario-based.php). Coastal topography is being updated to account for storm-driven and engineered changes to the coast associated with extreme storm recovery, coastal restoration, and mitigation. (For example, this report is based on topography that was updated post Hurricane 


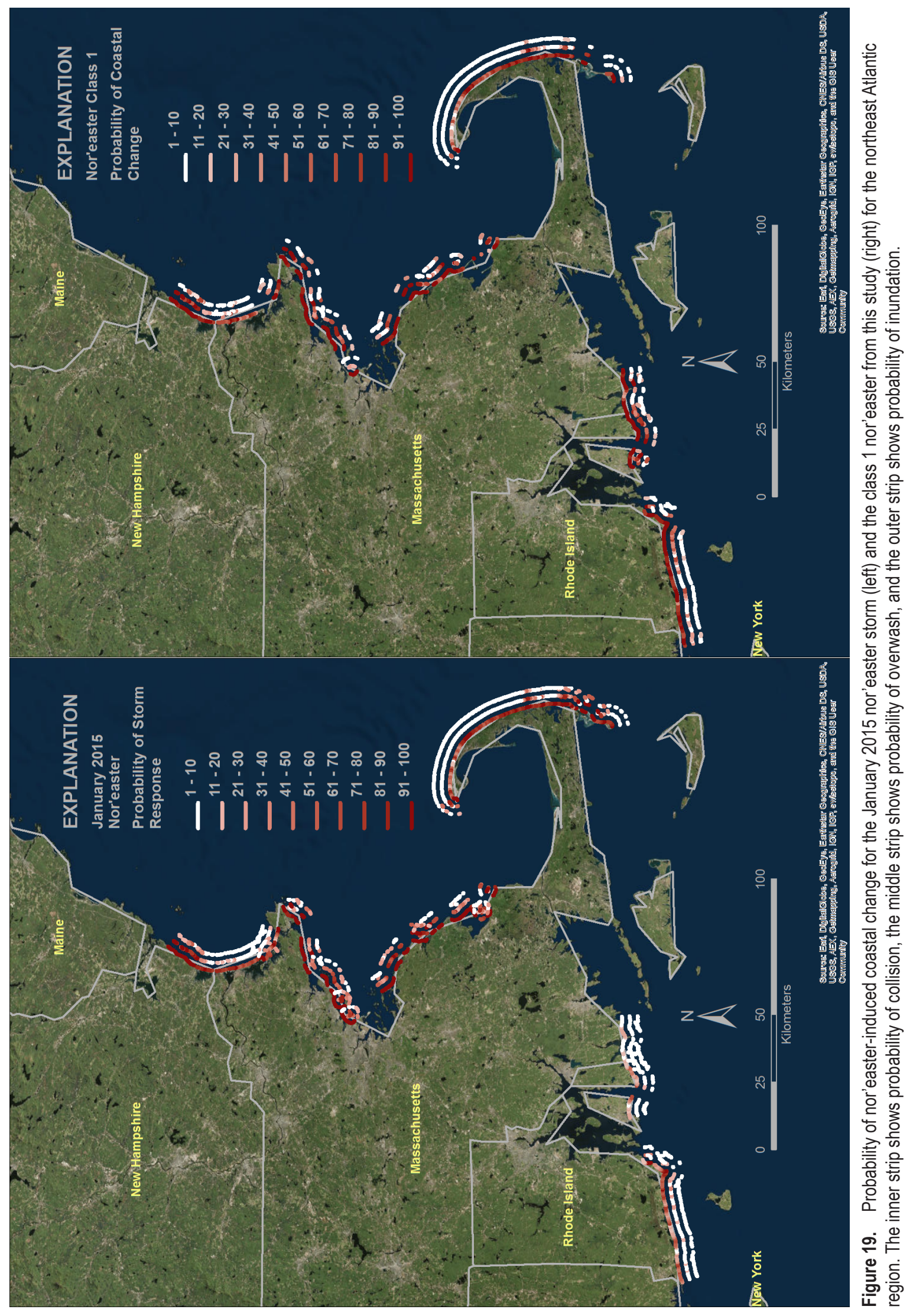


Sandy for those regions impacted by the storm.) This updating process is underway nearly continuously as USGS, the U.S. Army Corps of Engineers, State agencies, and other entities utilize increasingly effective lidar capabilities in acquiring coastal coverage for a variety of needs.

\section{Conclusions}

This assessment quantifies the probabilities of dune erosion, dune overwash, and beach/dune inundation when impacted by the worst-case scenario (high tide, maximum surge, maximum wave height) for class 1-3 nor'easters. The probabilities were calculated by comparing beach/dune elevations to modeled estimates of the nor'easter-induced total water level at the shoreline, including contributions from both waves and storm surge. The results of this assessment indicate that sandy beaches of the midand northeast Atlantic coast are vulnerable to coastal changes during landfall of even class 1 nor'easters; although not directly assessed, coastal infrastructure and habitat associated with those beaches are also likely to be vulnerable. The severity of these changes increases as the intensity of the storm-driven surge and waves increases and as the height of protective dunes decreases. Citizens and coastal managers who need to understand, plan for, and adapt to different levels of vulnerability may benefit from information on the likelihood of encountering mild, moderate, or severe erosion and deposition (overwash) associated with different storm intensities.

By including wave-driven setup and swash in addition to storm surge, we have identified the relative importance of waves in terms of their impact on erosion vulnerability. For class 1-3 nor'easters in this region, modeled wave runup is of greater magnitude than storm surge by roughly 75 percent. The mean $\eta_{R 2}$ ranged from 2.0 to $3.0 \mathrm{~m}$, and mean $\eta_{\text {surge }}$ ' ranged from 1.1 to $1.8 \mathrm{~m}$ for nor'easter classes 1-3, respectively. Analyses that ignore the wave component of this problem will underestimate erosion vulnerability for nor'easters, as well as cold fronts, tropical storms, and lower category hurricanes.

Though coastal elevations in the northeast are somewhat higher than along the mid-Atlantic coasts, the combination of steeper beach slopes and large surges makes the northeast region somewhat more vulnerable to substantial coastal erosion during similar nor'easter storm conditions. In the worstcase scenario of a class 1 nor'easter, 41 percent of dune-backed beaches along the mid- and northeast Atlantic coast are very likely $(p>0.9)$ to experience dune erosion during the collision regime. Overwash due to a class 1 nor'easter is very likely along 9 percent of the sandy coastline. During class 3 nor'easter conditions, 83 percent of the mid- and northeast Atlantic sandy beaches are very likely to experience collision, 32 percent of beaches are likely to experience overwash and associated erosion, and 6 percent of the beaches and dunes are very likely to be vulnerable to erosion caused by inundation. 


\section{References Cited}

Bidlot, J.-R., Holmes, D.J., Wittmann, P.A., Lalbeharry, R., and Chen, H.S., 2002, Intercomparison of the performance of operational ocean wave forecasting systems with buoy data: Weather and Forecasting, v. 17, no. 2, p. 287-310.

Birchler, J.J., Stockdon, H.F., Doran, K.S., and Thompson, D.M., 2014, National assessment of hurricane-induced coastal erosion hazards-Northeast Atlantic Coast: U.S. Geological Survey OpenFile Report 2014-1243, 34 p., accessed April 1, 2015, at http://dx.doi.org/10.3133/ofr20141243.

Butman B., Sherwood C.R., and Dalyander P.S., 2008, Northeast storms ranked by wind stress and wave-generated bottom stress observed in Massachusetts Bay, 1990-2006: Continental Shelf Research, v. 28, p. 1231-1245.

Chawla, A., Spindler, D.M., and Tolman, H.L., 2013, Validation of a thirty year wave hindcast using the Climate Forecast System Reanalysis winds: Ocean Modelling, v. 30, p. 189-206.

Chen, H.S., Behringer, D., Burroughs, L.D., and Tolman, H.L., 2004, A variational wave height data assimilation system for NCEP operational wave models: National Weather Service, National Centers for Environmental Prediction, MMAB 2004-04, 13 p.

Cubasch, U., Wuebbles, D., Chen, D., Facchini, M.C., Frame, D., Mahowald, N., and Winther, J.-G., 2013, Introduction, in Stocker, T.F., Qin, D., Plattner, G.-K., Tignor, M., Allen, S.K., Boschung, J., Nauels, A., Xia, Y., Bex, V., and Midgley, P.M., eds., Climate change 2013, The physical science basis, Contribution of Working Group I to the Fifth Assessment Report of the Intergovernmental Panel on Climate Change: Cambridge, Cambridge University Press, 1,535 p.

Davis, R.E., Demme, G., and Dolan, R., 1993, Synoptic climatology of Atlantic coast northeasters: International Journal of Climatology, v. 13.2, p. 171-189.

Derber, J.C., Parish, D.F., and Lord, S.J., 1991, The new global operational analysis system at the National Meteorological Center: Weather and Forecasting, v. 6, no. 4, p. 538-547.

Dolan, R., and Davis, R.E., 1992, An intensity scale for Atlantic coast northeast storms: Journal of Coastal Research v. 8, p. 352-364.

Doran, K.S., Stockdon, H.F., Sopkin, K.L., Thompson, D.M., and Plant, N.G., 2013, National assessment of hurricane-induced coastal erosion hazards-Mid-Atlantic Coast: U.S. Geological Survey Open-File Report 2013-1131, 28 p., accessed April 1, 2015, at http://pubs.usgs.gov/of/2013/1131/.

Funakoshi, Y., Feyen, J., Aikman, F., Tolman, H., van der Westhuysen, A., Chawla, A., Rivin, I., and Taylor, A., 2011, Development of Extratropical Surge and Tide Operational Forecast System (ESTOFS), in Estuarine and Coastal Modeling, American Society of Civil Engineers, p. 201-212.

Hart, R.E., and Grumm, R.H., 2001, Using normalized climatological anomalies to rank synoptic-scale events objectively: Monthly Weather Review, v. 129, no. 9, p. 2426-2442.

Hirsch, M.E., Degaetano, A.T., and Colucci. S.J., 2001, An East Coast winter storm climatology: Journal of Climate, v. 14 , no. 5 , p. 882-899. 
Mukai, A.H., Westerink, J.J., Luettich, R.A., Jr., Mark, D., 2002, Eastcoast 2001, A tidal constituent database for western North Atlantic, Gulf of Mexico, and Caribbean Sea: U.S. Army Corps of Engineers, ERDC/CHL TR-02-24, 196 p.

Plant, N.G., Holland, K.T., and Puleo, J.A., 2002, Analysis of the scale of errors in nearshore bathymetric data: Marine Geology, v. 191, no. 1-2, p. 71-86.

Plant, N.G., and Stockdon, H.F., 2012, Probabilistic prediction of barrier-island response to hurricanes: Journal of Geophysical Research Earth Surface, v. 117, F03015, doi:10.1029/2011JF002326.

Plant, N.G., Stockdon, H.F., Sallenger, A.H., Jr., Turco, M.J., East, J.W., Taylor, A.A., and Shaffer, W.A., 2010, Forecasting hurricane impact on coastal topography: Eos Transactions American Geophysical Union, v. 91, no. 7, p. 65-66.

Ruggiero, P., and List, J.H., 2009, Improving accuracy and statistical reliability of shoreline position and change rate estimates: Journal of Coastal Research, v. 25, no. 5, p. 1069-1081.

Saha, S., Moorthi, S., Pan, H., Wu, X., Wang, J., Nadiga, S., Tripp, P., Kistler, R., Woollen, J., Behringer, D., Liu, H., Stokes, D., Grumbine, R., Gayno, G., Wang, J., Hou, Y., Chuang, H., Juang, H. H., Sela, J., Iredell, M., Treadon, R., Kleist, D., Van Delst, P., Keyser, D., Derber, J., Ek, M., Meng, J., Wei, H., Yang, R., Lord, S., van den Dool, H., Kumar, A., Wang, W., Long, C., Chelliah, M., Xue, Y., Huang, B., Schemm, J., Ebisuzaki, W., Lin, R., Xie, P., Chen, M., Zhou, S., Higgins, W., Zou, C., Liu, Q., Chen, Y., Han, Y., Cucurull, L., Reynolds, R.W., Rutledge, G., and Goldberg, M., 2010, NCEP Climate Forecast System Reanalysis (CFSR) 6-hourly products, January 1979 to December 2010, Research Data Archive at the National Center for Atmospheric Research, Computational and Information Systems Laboratory, Dataset, accessed January 26, 2015, at http://dx.doi.org/10.5065/D69K487J.

Sallenger, A.H., 2000, Storm impact scale for barrier islands: Journal of Coastal Research, v. 16, no. 3 , p. 890-895.

Sallenger, A.H., Krabill, W., Swift, R., Brock, J., List, J., Hansen, M., Holman, R.A., Manizade, S., Sontag, J., Meredith, A., Morgan, K., and Stockdon, H., 2003, Evaluation of airborne scanning lidar for coastal change applications: Journal of Coastal Research, v. 19, p. 125-133.

Simpson, R.H., 1974, The hurricane disaster potential scale: Weatherwise, v. 27, p. 169 and 186.

Soulsby, R.L., and Whitehouse, R.J.S., 1997, Threshold of sediment motion in coastal environments, in Pacific Coasts and Ports '97, Christchurch, New Zealand, September 7-11, 1997: Proceedings of the 13th Australasian Coastal and Ocean Engineering Conference and the 6th Australasian Port and Harbour Conference, v. 1, p. 145-154.

Stockdon, H.F., Doran, K.J., Thompson, D.M., Sopkin, K.L., Plant, N.G., and Sallenger, A.H., 2012, National assessment of hurricane-induced coastal erosion hazards - Gulf of Mexico: U.S. Geological Survey Open-File Report 2012-1084, 51 p., accessed April 1, 2015, at http://pubs.usgs.gov/of/2012/1084/. 
Stockdon, H.F., Doran, K.S., and Sallenger, A.H., 2009, Extraction of lidar-based dune-crest elevations for use in examining the vulnerability of beaches to inundation during hurricanes: Journal of Coastal Research, v. 25, no. 6, p. 59-65.

Stockdon, H.F., Doran, K.S., Sopkin, K.L., Thompson, D.M., and Plant, N.G., 2013, National assessment of hurricane-induced coastal erosion hazards - Southeast Atlantic coast: U.S. Geological Survey Open-File Report 2013-1130, 34 p., accessed April 1, 2015, at http://pubs.usgs.gov/of/2013/1130/.

Stockdon, H.F., Holman, R.A., Howd, P.A., and Sallenger, A.H., 2006, Empirical parameterization of setup, swash, and runup: Coastal Engineering, v. 53, no. 7, p. 573-588.

Stockdon, H.F., Sallenger, A.H., Holman, R.A., and Howd, P.A., 2007a, A simple model for the spatially-variable coastal response to hurricanes: Marine Geology, v. 238, p. 1-20.

Stockdon, H.F., Thompson, D.M., and Sallenger, A.H., 2007b, Hindcasting potential hurricane impacts on rapidly changing barrier islands, in Proceedings, Coastal Sediments '07: Sixth International Symposium on Coastal Engineering and Science of Coastal Sediment Processes, New Orleans, Louisiana, May 13-17, 2007, American Society of Civil Engineers, p. 976-985.

Tolman, H.L. 2009, User manual and system documentation of WAVEWATCH III TM version 3.14, Technical note: National Oceanic and Atmospheric Administration, Marine Modeling and Analysis Branch Contribution No. 276.

Tolman, H.L., Balasubraminiyan, B., Burroughs, L.D., Chalikov, D.V., Chao, Y.Y., Chen, H.S., and Gerald, V.M., 2002, Development and implementation of wind-generated ocean surface wave models at NCEP: Weather and Forecasting, v. 17, no. 2, p. 311-333.

Wentworth, C.K., 1922, A scale of grade and class terms for clastic sediments: The Journal of Geology, v. 30, no. 5, p. 377-392.

Xue, Y., Huang, B., Hu, Z.-Z., Kumar, A., Wen, C., Behringer, D., and Nadiga, S., 2010, An assessment of oceanic variability in the NCEP climate forecast system reanalysis: Climate Dynamics v. 37 , no. 11-12, p. 2511-2539.

Zhang, K., Douglas, B.C., and Leatherman, S.P., 2001, Beach erosion potential for severe nor'easters: Journal of Coastal Research v. 17, p. 309-321.

Zielinski, 2002, A classification scheme for winter storms in the eastern and central United States with an emphasis on nor'easters: Bulletin of the American Meteorological Society v. 83, no. 1, p. 37-51. 
